\section{To: (Receiving Organization)}

DISTRIBUTION

5. Proj./Prog./Dept./Div.:

INTERIM STABILIZATION

\section{Originator Remarks}

ATTACHED IS A TEST REPORT FOR THE ACCEPTANCE TESTING OE PUMPING AND INSTRUMENTATION CONTROL SKID "N".

3. From: (Originating Organization)

INTERIM STABILIZATION

6. Design Authority/Design Agent/Cog. Engr.:

W. F. ZUROFE
4. Related EDT No.:

N/A

7. Purchase Order No:

$\mathrm{N} / \mathrm{A}$

9. Equip./Component No.:

$\mathrm{N} / \mathrm{A}$

10. System/Bldg./Facility:

241-G

12. Major Assm. Dwg. No.:

$\mathrm{N} / \mathrm{A}$

13. Permit/Permit Application No.

$\mathrm{N} / \mathrm{A}$

14. Required Response Date:

$1 / 31 / 00$

11. Receiver Remarks: 11A. Design Baseline Document? $O$ Yes $O$ No NONE
DATA TRANSMITTED

15.

(A)

(B) Document/Drawing No.

No.

\begin{tabular}{|l|l|}
$\begin{array}{c}\text { (C) Sheet } \\
\text { No. }\end{array}$ & $\begin{array}{c}\text { (D) Rev. } \\
\text { No. }\end{array}$ \\
\hline N/A & 0 \\
\hline
\end{tabular}

(E) Title or Description of Data Transmitted

(F)

(G)

(H)

(I)

Approval Reason Origi- Receiv

Desig- for Trans- nator Dispo-

nator mittal $\begin{gathered}\text { Dion } \\ \text { stion }\end{gathered}$

\begin{tabular}{|l|l|}
\hline 1 & $\mathrm{RPP}-5490$ \\
\hline & \\
\hline & \\
\hline & \\
\hline & \\
\hline & \\
\hline & \\
\hline
\end{tabular}

16.

\begin{tabular}{|c|l|}
\hline Approval Designator (F) & \\
\hline $\begin{array}{c}\text { E, S, Q, D OR N/A } \\
\text { (See WHC-CM-3-5, } \\
\text { Sec. 12.7) }\end{array}$ & $\begin{array}{l}\text { 1. Approval } \\
\text { 2. Release } \\
\text { Information }\end{array}$ \\
\hline
\end{tabular}

17.

Reason for Transmittal (G)

4. Review

6. Dist. (Receipt Acknow. Required)

TEST REPORT FOR ACCEPTANCE

TEST PROCEDURE FOR PUMPING

INSTRUMENTATION AND

CONTROL SKID "N" SIGNATURE/DISTRIBUTION

(See Approval Designator for required signatures)

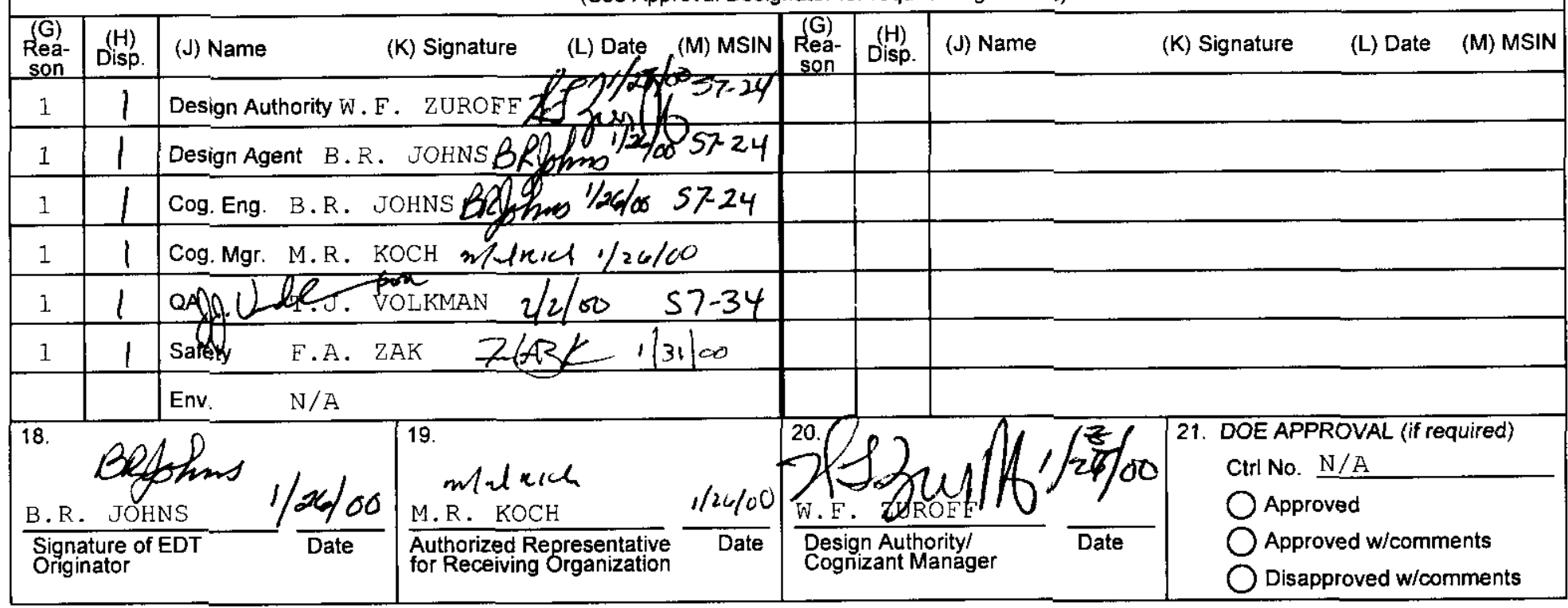




\title{
TEST REPORT FOR ACCEPTANCE TEST PROCEDURE FOR PUMPING INSTRUMENTATION AND CONTROL SKID "N"
}

\author{
M. R. KOCH \\ CH2MHILL HANFORD GROUP, INC. \\ Richland, WA 99352 \\ U.S. Department of Energy Contract DE-AC06-96RL13200
EDT/ECN: $624867 \quad$ UC:
Org Code: 74D00 Charge Code: 103361 \\ B\&R Code: Ew3120071 Total Pages: 54
}

Key Words: PICS, SALT WELL, SKID, INTERIM STABILIZATION, TESTING

\begin{abstract}
:
This is a Test Report for Acceptance Test Procedure (ATP) RPP-5489.

This test report provides the results of the inspection and testing of the new Pumping Instrumentation and Control (PIC) skid designed as " $N$ ". The ATP was successfully completed. A copy of the completed ATP is in the Appendix of this document.
\end{abstract}

TRADEMARK DISCLAIMER. Reference herein to any specific commercial product, process, or service by trade name, trademark, manufacturer, or otherwise, does not necessarily constitute or imply its endorsement, recommendation, or favoring by the United States Government or any agency thereof or its contractors or subcontractors.

Printed in the United States of America. To obtain copies of this document, contact: Document Control Services, P.O. Box 950, Mailstop H6-08, Richland WA 99352, Phone (509) 372-2420; Fax (509) 376-4989.

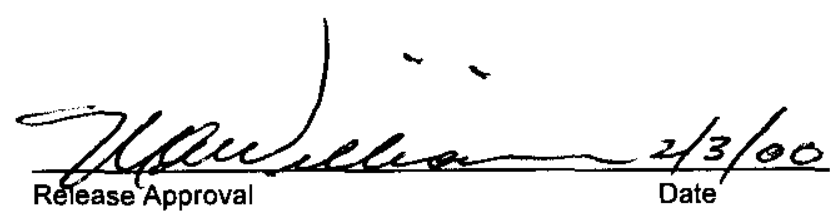

Approved For Public Release 


\section{TEST REPORT FOR ACCEPTANCE TEST PROCEDURE FOR PUMPING INSTRUMENTATION AND CONTROL SKID "N"}

\subsection{INTRODUCTION}

This test report provides the results from the performance of Acceptance Test Procedure (ATP) RPP-5489, for Pumping Instrumentation and Control (PIC) skid "N". The ATP verifies the proper construction of the PIC skid "N" by Site Fabrication Services along with proper programming of the Programmable Logic Controller (PLC) by engineering. New PIC skid " $N$ " will be used for the pumping of tank U-109. A copy of the actual test results is in the Appendix of this document.

\subsection{DESCRIPTION OF TEST}

The test was performed at the Site Fabrication Services location. The ATP ensured the PIC skid was assembled and functioned as per the design drawings. Inputs to the skid were simulated to ensure proper equipment connections and wiring.

The ATP document provided detailed instructions for each test step and spaces for recording the data and signoffs. A copy of the test results including exceptions is in the Appendix.

\subsection{TEST METHOD AND TEST EQUIPMENT}

The ATP detailed the test methods and the test equipment to be used for testing. Test equipment identification and calibration dates are recorded on the ATP data sheets. Quality Control and Engineering witnessed the performance of the ATP. 
RPP-5490

REVISION 0

\subsection{TEST RESULTS}

The ATP was successfully completed. Discrepancies in the test procedure were listed as exceptions. All the exceptions identified became part of the ATP and are in the Appendix along with the ATP results. Exception 1 is an editorial change that corrected two alarm numbers and is only recorded on the exception log, but not on an exception record sheet. Exceptions 2 and 3 are recorded on exception records and were reviewed, resolved and signed off as closed for this ATP.

A National Electrical Code (NEC) inspection was performed as part of the ATP. The NEC inspector accepted the electrical power portion of the skid and placed a blue acceptance sticker on the distribution panel. A Pressure Vessel inspector checked the water and air compressor tanks along with the associated relief valves. The installation of these tanks was acceptable. The relief-valves were functional checked as part of the ATP. Copies of the NEC and Pressure Vessel inspection reports are in the Appendix of this document.

\subsection{CONCLUSIONS AND RECOMMENDATIONS}

The PIC skid is found to be ready for field operation. All exceptions were resolved. An Operational Test Procedure (OTP) will be performed after the skid is set up for field configuration.

\subsection{REFERENCES}

RPP-5489, REVISION 0, ACCEPTANCE TEST PROCEURE FOR PUMPING AND INSTRUMENTATION CONTROL SKIDS, Lockheed Martin Hanford Corporation, Richland, Washington.

2H9904137, Site Fabrication Services work package. 
RPP-5490

REVISION 0

\subsection{APPENDIX}

Copy of ATP, RPP-5490, Revision 0 (Partial, includes only the ATP pages where data was recorded.

NEC Inspection Report

Pressure Vessel Inspection Report 


\subsection{PREREQUISITES}

\subsection{DRAWING VERIFICATION}

A check of the constructed skid is to be compared to either the redlined drawings or the final unreleased skid drawings. Engineering and Quality Assurance shall verify the accuracy of the essential and support drawings. Engineering shall determine a resolution for all discrepancies by either correcting the drawings or changing the equipment.

The following drawings shall be walked down for verification of proper construction of the skid:

4.1.1 Wire terminations and wiring labels on drawings $\mathrm{H}-14-103784$, sheets 7 through 12 and $\mathrm{H}-14-103787$, sheet 5.

4.1.2 Panel board arrangement on drawing H-14-103790.

4.1.3. Flow diagrams on drawings $\mathrm{H}-14-103784$, sheet 5 and $\mathrm{H}-14-103789$.

Drawing verification completed. (Final drawing release is not required to continue with this ATP.)

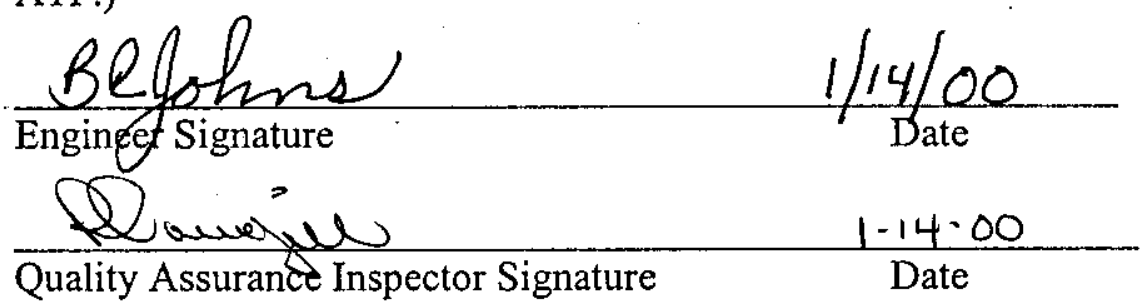

\subsection{REDLINE INCORPORATION}

4.2.1 BRO/Ensure the relines identified on the construction drawings in the fabfication work package are incorporated on the final drawings for skid " $\mathrm{N}$ " prior to the drawings being released. NOTE: Redlines must meet the intent of the markups and may not be exactly the same in order to meet drafting standards or for clarity.

4.2.2 Engineer to verify the redline incorporation is completed by signing below.

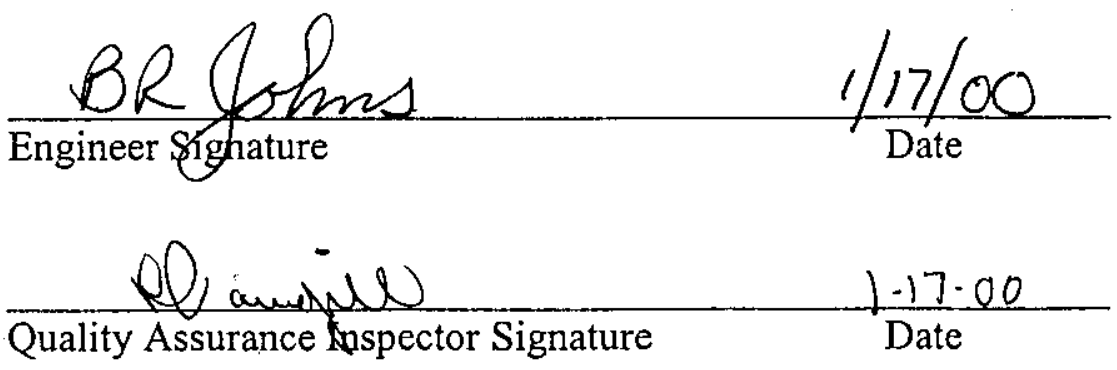




\subsection{PRESSURE VESSEL INSPECTION}

A pressure vessel inspection by a third party inspector is required for the air compressor receiver tank and relief valves located in the air compressor cabinet and the water tank and relief valves located in the water cabinet. The inspection is to verify that the equipment meets National Codes for pressure vessels. An outside-certifies inspector shall perform this inspection. (This inspection shall be completed prior to testing the air compressor and water systems.)

Pressure vessel inspection report received. (The ATP can continue before the report is received, but must be received prior to performing section 5.6.)

Report \#'s: TANK TPI-WT-144 + TPI-WT-145

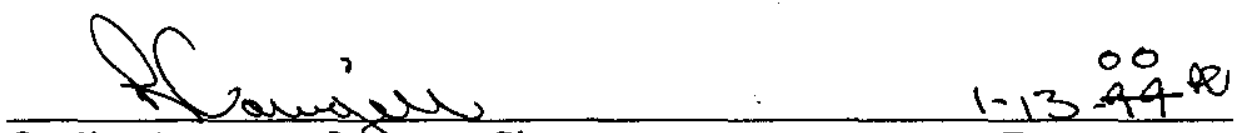

Quality Assurance Inspector Signature Date

Information has been supplied to the PMS database to add relief valve inspection for the air compressor and water tanks. Completion of the database update will be tracked by the Acceptance for Beneficial Use documentation.

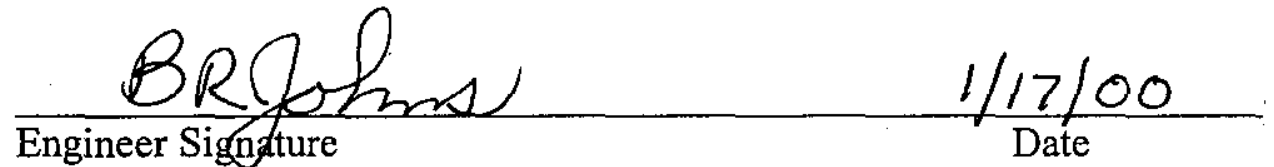

\subsection{NATIONAL ELECTRICAL CODE (NEC) INSPECTION}

4.3.1 An NEC inspection shall be performed to verify compliance to NFPA 70, latest version.

4.3.2 Areas in particular to be inspected are the $480 \mathrm{vac}$ and $120 \mathrm{vac}$ wiring and grounding.

4.3.3 An NEC inspection sticker is to be placed on the inside or the outside of the panel board door upon the NEC inspector's acceptance of the electrical portion of the skid.

The NEC inspection sticker is placed on the panel board door and the NEC report received.

(This needs to be completed prior to the section 5.0 functional checks.) Report \# 8153 sticker 8168 Report Bg.

$\frac{\text { Demiged }}{\text { Quality Assurance Inspector Signature }} \frac{1-17.00}{\text { Date }}$




\subsection{SUPPLIES}

The following supplies are required for this ATP.

NOTE: Test sections may commence prior to assembly of all the test equipment. Engineer and/or PIC are to ensure test equipment is available prior to the start of each section.

\subsubsection{Volt/ohm meter (VOM): Portable, 0-600vac}

Calibration No. $817-45-08-068$ Exp. Date 3-22-00 QA

Calibration No. Exp. Date QA

Calibration No. Exp. Date QA

\subsubsection{Transmation current (milliamp) simulator or equivalent}

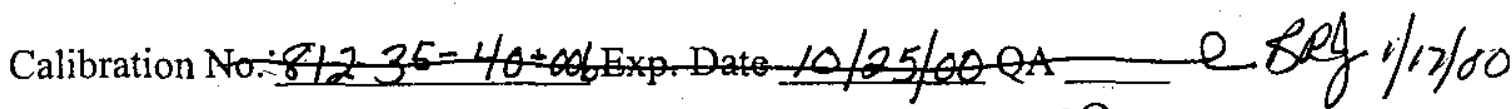
Calibration No. 817:13-20-031 Exp. Date 3/31/00 QALU Calibration No. 817-13-20-024 Exp. Date 10/13/00 QA \& Calibration No. 8/7-35-40-053Exp. Date 2/12/00 QA QL Calibration No. Exp. Date QA

\subsubsection{Manometer capable of a minimum of 5 inches water gauge to a maximum of} 125 inches water gauge for this ATP and a read-out of variable test pressure.

Calibration No. 812-35-40-006 Exp. Date 10/25/00 QA Q

Calibration No. Exp. Date $\mathrm{QA}^{-}$

Calibration No. Exp. Date QA

\subsubsection{Megaohm meter, at least 500vac range.}

Calibration No. 817.45.45-012 Exp. Date 9.17 00 QA Q

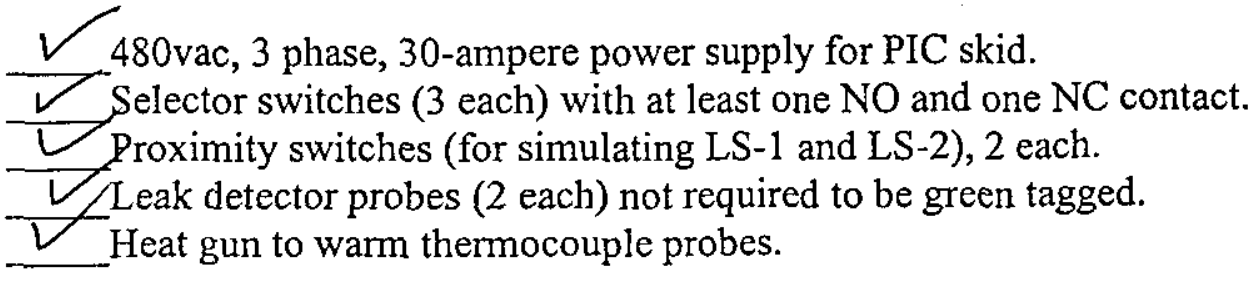

\section{QC INSPECTION RECORD


4.4.10 A thermocouple simulator for testing the thermocouples for the pump and jumper..

4.4.11 Buckets or pans for water for leak detector test and catching water from DIP tubes and relief valves.

4.4.12 Water supply and hose to fill water tank. 


\subsection{PRESTART CONDITIONS}

4.5.1 $80 \mathrm{~g}$ Fill the water tank at least one-third to half full of water. Operate the appropriate valves in the water cabinet to accomplish this task.

4.5.2 BRy Ensure the PIC skid is grounded in preparation for ATP testing.

4.5.3 BR Ensure the following PIC skid valves in the WFIE cabinet are OPEN prior to starting this ATP.

BRy SALW-V-6035N (EQUALIZING)
BRYSALW-V-6036N (EQUALIZING) 4.5.4 BQD Ensure the following PIC skid valves are CLOSED prior to starting this

Air Compressor Cabinet

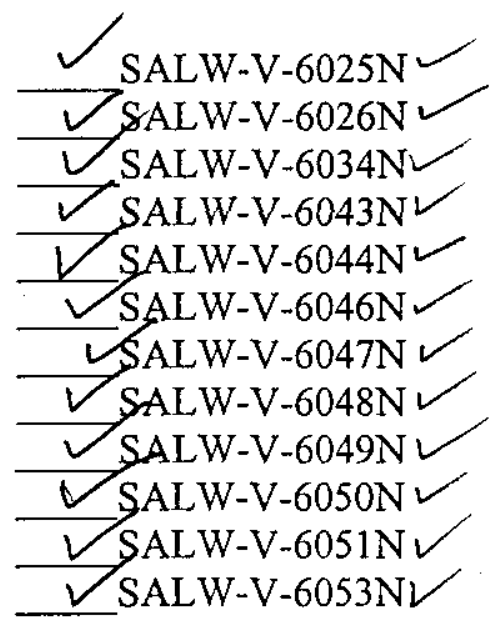

Water Cabinet

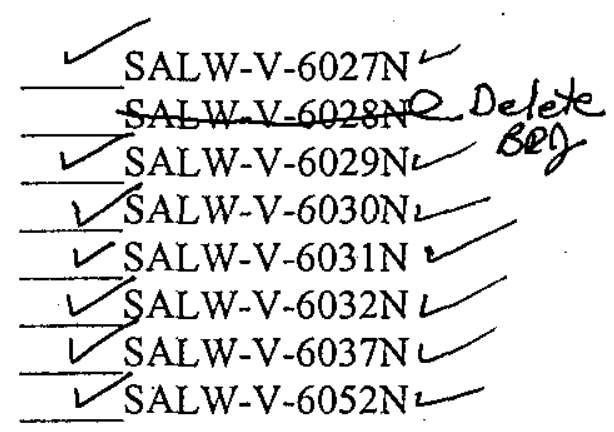

WFIE Cabinet
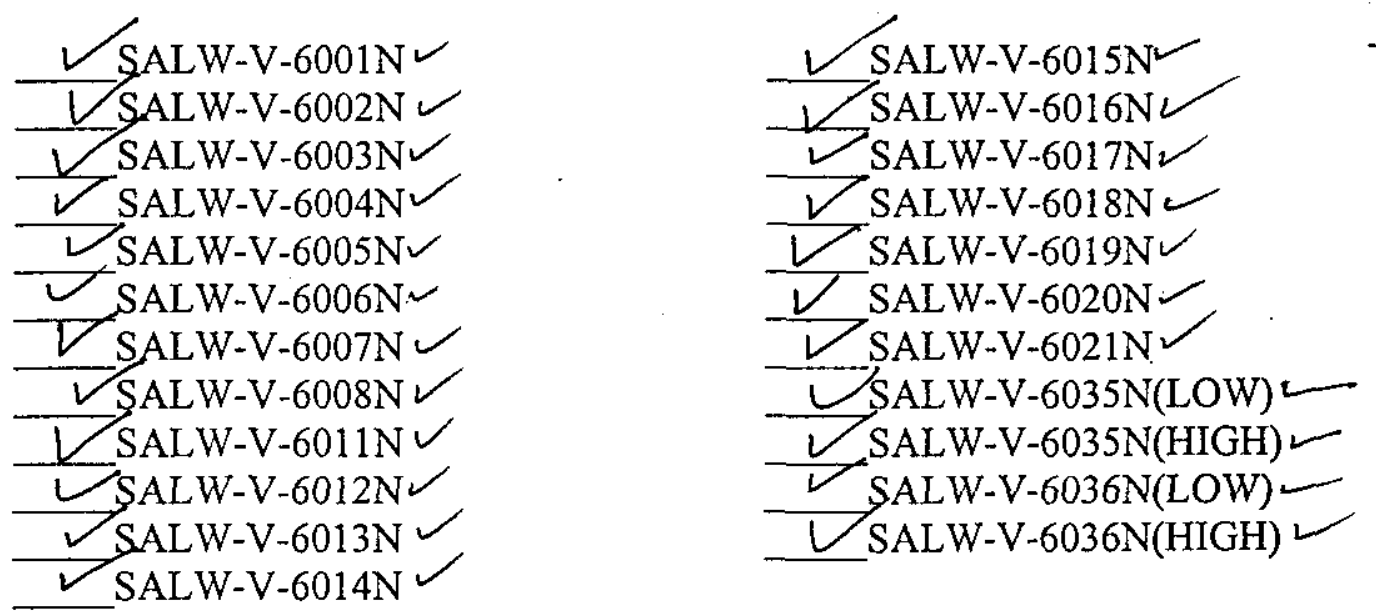

QC INSPECTION RECORO

10OF-51-

PAGE A 5 OF A 50 
4.5.5 R Ensure the following PIC skid circuit disconnects, breakers and fuses are OPEN or OFF prior to starting this ATP.

BO SALW-DS-6002N
BACSSALW-DS-6004N

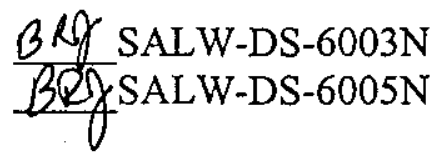

(The following breakers are located in distribution panel SALW-DP6001N.)
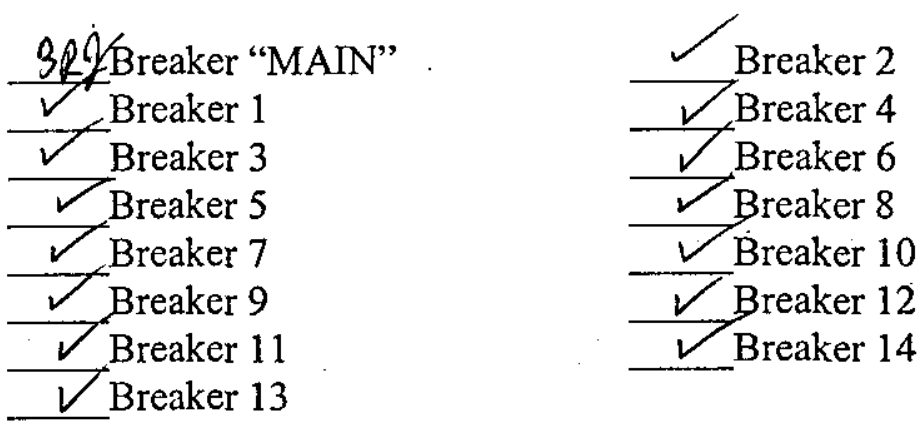

(The following fuses are located in the Instrument Enclosure.)
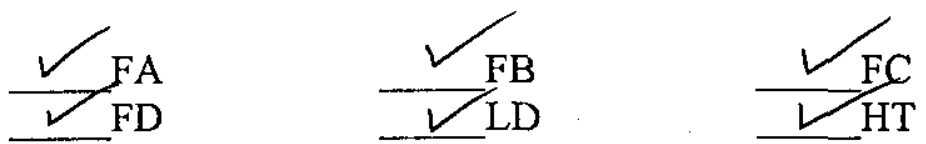

4.5.6 Check for loose electrical connections at the following locations:

Terminal boards in the Instrument Enclosure.

Motor starters and disconnect switches.

$\checkmark$ Jerminal board in junction box inside the WFIE cabinet.

- Jerminal board in heat trace splice box outside WFIE cabinet.

$\checkmark$ Terminal board in junction box for FGM outside WFIE cabinet.

Distribution panel board.

4.5.7 BOA Ensure desiccant and filters are installed in the air compressor dryer and filtersprior to performing sections 5.6 and 5.7.

4.5.8 $B \cap 0$ A pre-job safety meeting shall be held prior to performing section 5.0. 


\subsection{PROCEDURE}

\subsection{CONTINUITY CHECKS}

Continuity checks shall be performed with a calibrated VOM. Perform the checks as identified below. Readings are to be less than $1 \mathrm{ohm}$. Record ohm readings on the line(s) provided. Out of tolerance readings must be corrected and rechecked prior to going to the next section. NOTE: NEC inspection must be completed prior to proceeding with this section.

5.1.1 480vac main power plug to the line side of the main disconnect switch (SALW-DS-6002N). Check all three phases and ground.

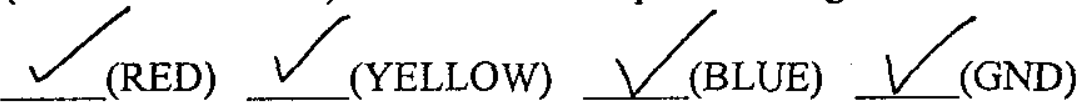

5.1.2 Load side of main disconnect switch (SALW-DS-6002N) to the line side of transformer disconnect switch (SALW-DS-6003N). Check the two phases used and ground.

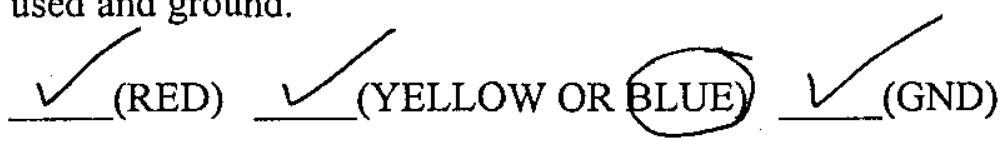

5.1.3 Load side of main disconnect switch (SALW-DS-6002N) to the line side of the jet pump motor starter (SALW-DS-6005N). Check all three phases and ground.

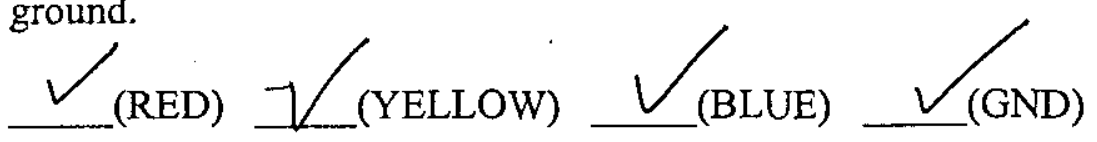

5.1.4 Load side of main disconnect switch (SALW-DS-6002N) to the line side of the air compressor motor starter (SALW-DS-6004N). Check all three phases and ground.

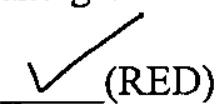

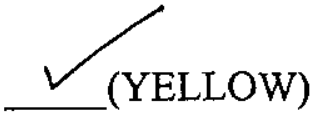<smiles>CC1CCCC(C)(Br)C1(C)C</smiles><smiles>CCCC(C)C(=O)O</smiles>

5.1.5 Load side of the transformer disconnect switch (SALW-DS-6003N) through the primary of the transformer (SALW-XFMR-6001N). Check between the two phase, wires going to the transformer.

Continuity through the transformer primary. 
5.1.6 Line side of the main breaker in panel board (SALW-DP-6001N) through the secondary of transformer (SALW-XFMR-6001N). Check between the two phases and between each phase and neutral going to the transformer secondary.

Phase A to phase $\mathrm{C}$, continuity through transformer secondary.

Phase A to neutral, continuity through transformer secondary.

Phase $\mathrm{C}$ to neutral, continuity through transformer secondary.

5.1.7 Load side of breakers in distribution panel (SALW-DP-6001N) to terminal point identified.

Circuit 3 to TB10 in Instrument Enclosure (CKT3-H, CKT3-N)

Gircuit 5 to TB13 in Instrument Enclosure (CKT5H, CKT5N)

Gircuit 12 to Air Conditioner/Heater receptacle in Instrument Enclosure

$\checkmark$ Circuit 6 to safe side terminal block in Intrinsic Safe panel

$\checkmark$ Gircuit 1 to terminal block in FGM power junction box

$\checkmark$ Circuit 11 to terminal block in FGM power junction box

Gircuit 13 to terminal block in FGM power junction box

Circuit 14 to terminal block in FGM power junction box

$\checkmark$ Circuit 2 to terminal block in FGM heat trace splice box

$\checkmark$ ircuit 10 to terminal block in FGM heat trace splice box

$\checkmark$ Circuit 4 to receptacle in air compressor cabinet

$\checkmark$ Gircuit 7 to receptacles in WFIE cabinet

$\checkmark$ Circuit 8 to receptacle in water cabinet

$\checkmark$ Circuit 9 to outside receptacle below panel board

5.1.8 Section 5.1 completed and all recorded readings within tolerance. BRg $1 / 14 / 00$

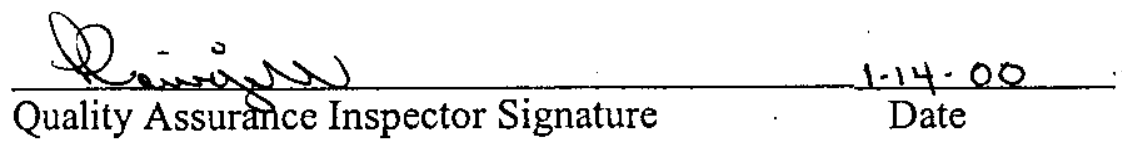

\section{QC INSPECTION RECORO}




\subsection{MEGGERING OF POWER WIRES}

The power wires shall be checked for resistance to ground and phase to phase. A 500-volt megger shall be used for this check. Minimum acceptable readings are greater than 1000 megaohm or infinity. Test the circuits listed below. Record readings on the lines provided. Out of tolerance readings must be corrected and rechecked prior to going to the next section.

5.2.1 Each of the three phases at the pins of the power plug to ground and phase to phase. (Ensure main disconnect SALW-DS-6002N is OPEN.)
A-GND $\infty$; $\mathrm{B}-\mathrm{C} \infty$
B-GND $\infty$
$\mathrm{C}-\mathrm{GND} \infty ; \mathrm{A}-\mathrm{B} \infty$; $\mathrm{A}-\mathrm{C} \propto$

5.2.2 Each of the three phases at the load side of the main disconnect switch (SALW-DS-6002N) to ground and phase to phase. (Ensure switches SALWDS-6003N, SALW-DS-6004N and SALW-DS-6005N are OPEN.)
A-GND $\infty$
; B-GND $\infty$;
C-GND
$\stackrel{\infty}{\infty}$
A-B $\infty$
A-C $\stackrel{\infty}{-}$
B-C $\infty$

5.2.3 Each of the two phases on the load side of the transformer disconnect switch (SALW-DS-6003N) to ground.
A-GND $\infty$;
B-GND $\infty$

5.2.4 Each of the three phases on the load side of the air compressor motor to ground.
$\mathrm{A}-\mathrm{GND} \infty$; $\mathrm{B}-\mathrm{GND} \infty$; $\mathrm{C}-\mathrm{GND} \perp$ Disconnect the neutral at the distribution panel from ground.

5.2 .5

5.2.6 Each of the two phases and neutral to ground at the distribution panel.

5.2.7 Reconnect the neutral back to ground at the distribution panel.

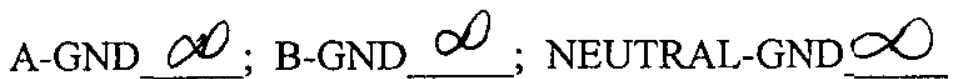

5.2.8 Disconnect the circuit 6 wire at the safe side terminal block in the Intrinsic Safe panel.

Ensure all the heaters, lights and air conditioner are disconnected or unplugged from the 120vac circuits. Weed to disconn ect In str End. I.ght at TB 13. BRg

\section{QC INSPECTION RECORI}


5.2.10 Megger each of the 14 circuits from the load side of the breaker or from the wire disconnected at the load side of the breaker to ground in the distribution panel.

NOTE: Disconnect each wire from the load side of the breaker on all the ground fault breakers prior to performing the megger check. This will prevent damage to the ground fault circuitry in the breaker. Reconnect the wire after meggering.

CKT \#1 to GND $\frac{\infty}{\infty}$
CKT \#3 to GND $\frac{\infty}{\infty}$
CKT $\# 5$ to GND $\frac{\infty}{\infty}$
CKT \#7 to GND $\frac{\infty}{\infty}$
CKT \#9 to GND $\frac{\infty}{\infty}$
CKT \#11 to GND $\frac{\infty}{\infty}$
CKT \#13 to GND $\infty$

CKT \#2 to GND $\frac{\infty}{\infty}$
CKT \#4 to GND $\frac{\infty}{\infty}$
CKT \#6 to GND $\frac{\infty}{\infty}$
CKT \#8 to GND $\frac{\infty}{\text { CKT \#10 to GND } \frac{\infty}{\infty}}$
CKT \#12 to GND $\frac{\infty}{\text { CKT \#14 to GND }}$

5.2.11 Ensure the load-side wire at each breaker where disconnected is reconnected.

5.2.12 Reconnect the circuit 6 wire to the safe side terminal block in the Intrinsic safe panel.

5.2.13 Reconnect any wires disconnected in step 5.2.9 above. (Unplugged items do not have to be plugged back in.) $C K+5$ at TB 13 BA

5.2.14 Section 5.2 completed and all recorded readings are within tolerance.

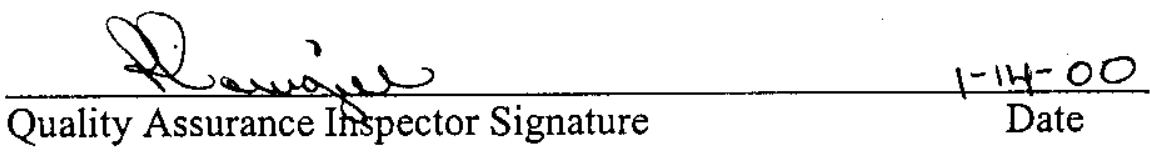




\subsection{ELECTRICAL POWER CHECKS}

The voltage checks are to verify proper voltages throughout the skid at specific termination points. Voltages checked are $480 \mathrm{vac}, 3$ phase; $120 \mathrm{vac}$, single phase; $24 \mathrm{vdc}$; and $32 \mathrm{vdc}$. Out of tolerance readings must be corrected when found before going to the next step in this section.

5.3.1 BQ Ensure that all electrical connections are completed. Wires lifted during meggering checks are to be reconnected.

5.3.2 BQl Ensure all switches and breakers are open and the six fuses in the Instaument Enclosure are open.

5.3.3 BQQ Ensure all the fuses are installed in the two safety switches (SALW-DS. 6002N and SALW-DS-6003N) and motor starters (SALW-DS-6004N and SALW-DS-6005N) including the control transformer fuses.

5.3.4 B. Connect the main power plug on the skid to a three phase, $480 \mathrm{vac}$ power source. Source is to be protected by no greater than a 30 ampere over current protection device.

5.3.5 BR. Turn ON the power source to the skid.

5.3.6 2 Ensure $480 \mathrm{vac}+/-20 \mathrm{vac}$ on the line side of the main disconnect switch (SALW-DS-6002N). Record the voltage readings.
492 vac, $A-B$
495 A-C
497 B-C

5.3.7 820 Close the main disconnect switch (SALW-DS-6002N).

5.3.8 Bol Ensure $480 \mathrm{vac}+/-20 \mathrm{vac}$ on the line side of the transformer disconnect switch (SALW-DS-6003N). Record the voltage readings.

495 vac

5.3.9 B 8 Ensure 480vac $+/-20 \mathrm{vac}$ on the line side of the air compressor motor starter (SALW-DS-6004N). Record the voltage readings.
492 vac, A-B
495 vac, A-C
496 B-C

5.3.10 B Ensure $480 \mathrm{vac}+/-20 \mathrm{vac}$ on the line side of the pump motor starter (SALW-DS-6005N). Record the voltage readings.
492 vac, $A-B$
495 vac, $\mathrm{A}-\mathrm{C}$
$496 \quad$ B-C

\section{OC INSPECTION RECORE}


5.3.11 BQY Remove the dead front on the panel board (SALW-DP-6001N) for access to the main breaker for a voltage measurement.

5.3.12 Bay Close the transformer disconnect switch (SALW-DS-6003N).

5.3.13 BQ Check for 240vac +/-20vac on the line side of the main breaker. Record the voltage reading.

248 vac

5.3.14 Bed Open the transformer disconnect switch (SALW-DS-6003N).

5.3.15 BR (Replace the dead front on the panel board (SALW-DP-6001N).

5.3.16 Bef Close the transformer disconnect switch (SALW-DS-6003N). 5.3.17 $\frac{\mathrm{B} A \mathrm{C} \text { Close the } 100 \text { ampere main breaker in the panel board (SALW-DP- }}{600 \mathrm{~N} \text { ). }}$

5.3.18 Check the voltages for the circuits at the locations designated. Record the voltages in the space provided.

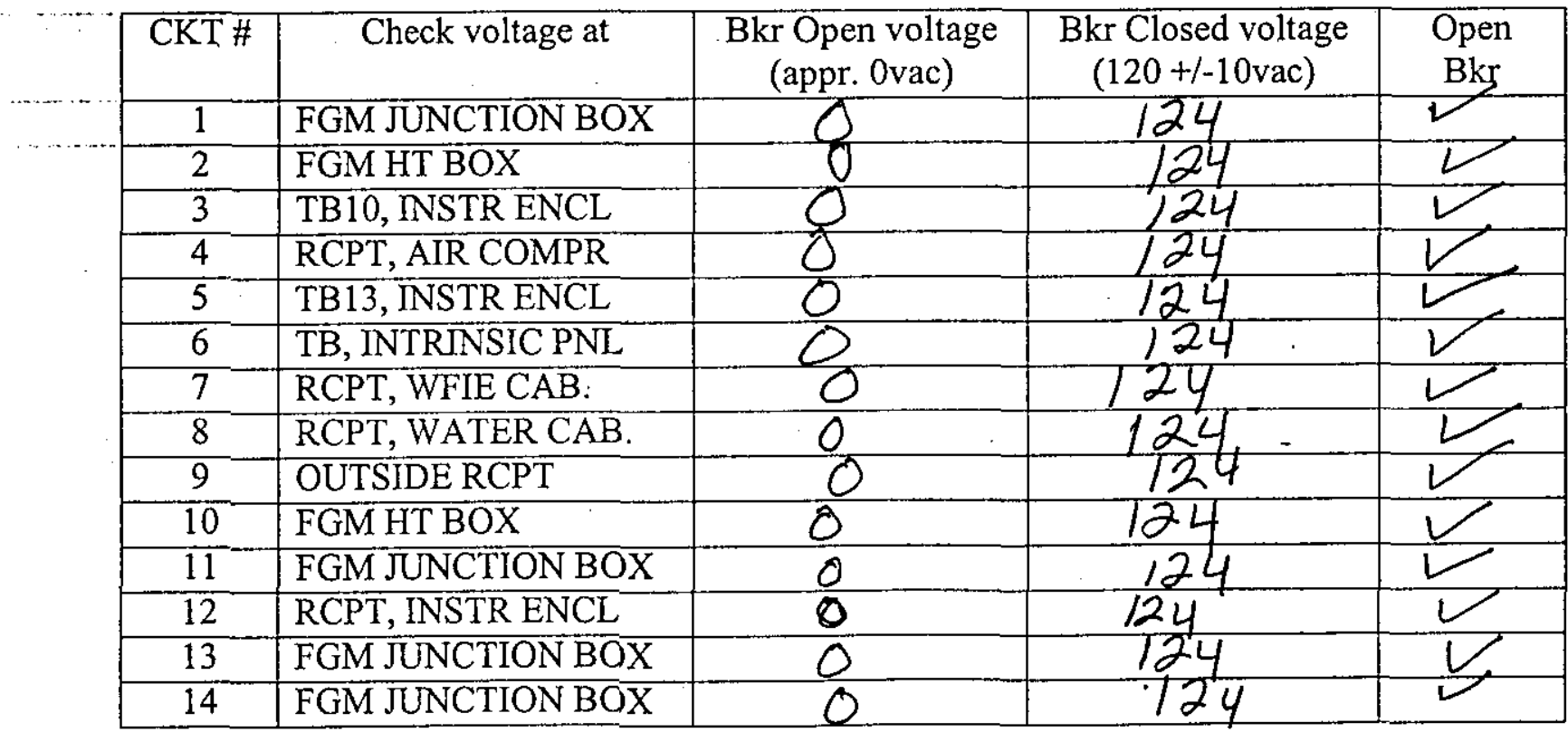

\section{AC INSPECTION RECORO}


5.3.19 B. Ensure fuses FA, FB, FC, FD, LD, and $\mathrm{HT}$ are installed in the fus oholders in the Instrument Enclosure.

5.3.20 B Close breakers 3 and 5 in the distribution panel (SALW-DP-6001N). 5.3.21 30 Ensure 120vac $+/-10 \mathrm{vac}$ on the line side at the following fuseholder
load side points.
FA_ 2.4 vac;
$\mathrm{FB} 124$ $\operatorname{vac}$
$\mathrm{FC} 124$ vac;
FD 124 vac;
LD $124 \quad \mathrm{vac}$
HT 124 vac.

5.3.22 BRy Ensure $24 \mathrm{vdc}+/-2 \mathrm{vdc}$ at each 24 volt power supply.

First power supply $23.8 ; \quad$ Second power supply 23.8 .

5.3.23 BACClose breaker 6 in the distribution panel (SALW-DP-6001N).

5.3.24 BRe Ensure 32vdc +0/-4vdc at the output of the 3991 power supply in the Intrinsic safe panel (terminals 3 and 4). NOTE: Low voltage reading may indicate the 240/120vac input power switch on the side of the 3991 supply is in the wrong position.) 32.7 VDC

5.3.25 BRf Open breakers 3, 5 and 6 in the panel board (SALW-DP-6001N).

5.3.26 $\mathrm{BeV}$ Open the 100 ampere main breaker in the panel board (SALW-DP-
$6001 \mathrm{~N}$ ).

5.3.27 BeY Open the transformer disconnect switch (SALW-DS-6003N).

5.3.28 Bay (Open the main disconnect switch (SALW-DS-6002N).

5.3.29 Voltage checks completed and readings within tolerance.

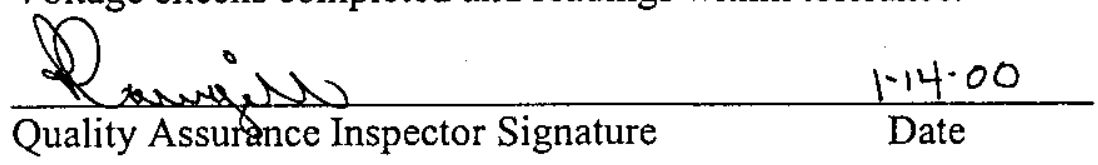




\subsection{CALIBRATIONS}

Instrumentation equipment on the skid requires calibration prior to the functional testing. Engineering will verify the calibration completion by checking for current calibration stickers on the equipment and checking off the completed calibrations in the table below.

\begin{tabular}{|l|l|l|}
\hline \multicolumn{1}{|c|}{ INSTRUMENT } & \multicolumn{1}{c|}{ LOCATION } & CAL. STICKER ON \\
\hline SALW-PS-6004N & AIR COMPR. CABINET & \\
\hline SALW-WFT-6002N & WFIE CABINET & \\
\hline SALW-LT-6003N & WATER CABINET & \\
\hline SALW-SGT-6001N & WFIE CABINET & \\
\hline SALW-CONV-6001N & WFIE CABINET & \\
\hline SALW-FQIT-6001N & INSTRUMENT ENCL. & \\
\hline SALW-PI-6006N & AIR COMPR. CABINET & \\
\hline SALW-PI-6007N & AIR COMPR. CABINET & \\
\hline SALW-PI-6008N & WATER CABINET & \\
\hline SALW-PI-6001N & WFIE CABINET & \\
\hline SALW-PI-6002N & WFIE CABINET & \\
\hline SALW-PI-6003N & WFIE CABINET & \\
\hline SALW-PI-6004N & WFIE CABNET & \\
\hline SALW-PI-6005N & WFIE CABINET & \\
\hline SALW-PI-6011N & INSTRUMENT ENCL. & \\
\hline SALW-PI-6012N & INSTRUMENT ENCL. & \\
\hline
\end{tabular}

Calibrations completed. Work package nos. $2 w-99-1776$ to 1781

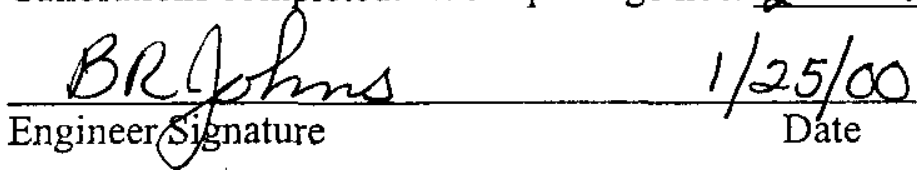

\subsection{PLC/DTAM PROGRAMMING}

This section is where the programs for the PLC and DTAM will be entered into the equipment. Power will be required (circuit 5) at the Instrument enclosure to power up the PLC and DTAM and for the GFCI receptacle. Engineering will program the equipment from a laptop computer. Final software programs shall be documented as required by HNF-5034. This documentation is not part of this ATP, but will be documented after the OTP in document RPP-5492.

PLC/DTAM programmed.

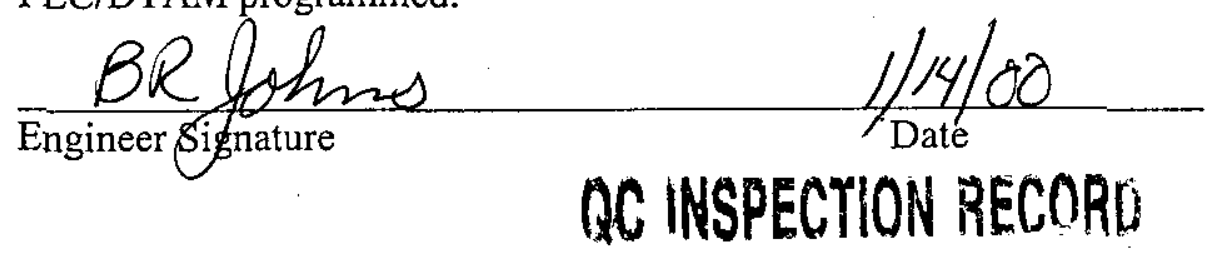

190F 51

PAGE A 14 OF A 50 


\subsection{SKID ELECTRICAL AND PROCESS AIR POWER-UP}

NOTE: The pressure vessel inspection report must be received prior to proceeding with this section. Refer to section 4.3. Ensure desiccant is in the air dryer and the filters installed.

5.6.1 BQS Ensure the skid is connected to the 480vac power source and grounded before proceeding with this functional test.

5.6.2 B E Energize or ensure energized the PIC skid by CLOSING the following discohnect switches in the order listed below.

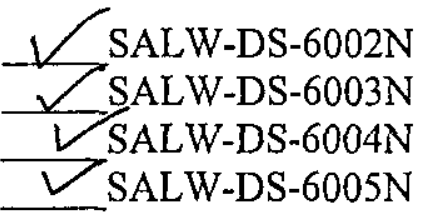

5.6.3 304 Energize or ensure energized the breakers in the panel board (SALWDP-6001N).
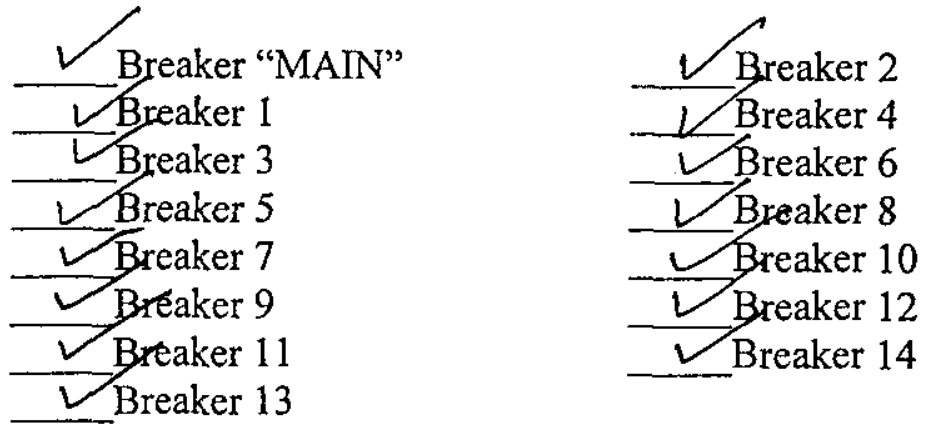

5.6.4 BlY ACKNOWLEDGE any initial skid alarms.

5.6.5 Bef OPEN valves SALW-V-6034N, SALW-V-6050N, and SALW-V$605 \mathrm{BN}$ in the Air compressor cabinet.

5.6.6
SALN START the air compressor by positioning the positioning the switch on
S

5.6.7 $B \propto 0 /$ Ensure the air compressor starts and builds up pressure and shuts off at 86 to 94 psig as indicated by pressure gauge SALW-PI-6006N. RECORD the shut off pressure: 90 psig.

5.6.8 3 CHECK the tubing in the air compressor cabinet using a soap and water test to visually identify any air leaks. Repair as necessary. Deenergize the compressor motor and bleed off air as necessary to make repairs.

\section{OC INSPECTION RECORO}


5.6.9 BA BLEED off air by slowly opening valve SALW-V-6043N until the compressor restarts and note the restart pressure as read on gauge SALW-PI$6006 \mathrm{~N}$. CLOSE valve SALW-V-6043N when the compressor restarts. RECORD the restart pressure reading: psig.

5.6.10 BR2 ENSURE the compressor restarts between 58 to 62 psig.

5.6.11 Valve in air to the PIC skid water tank by performing the following steps.

5.6.12 Check for air leaks as each of the remaining steps in this section are performed.

5.6.13 SLOWLY OPEN valve SALW-V-6025N located in the air compressor cabinet.

5.6.14 SLOWLY OPEN valve SALW-V-6027N located near the water tank.

5.6.15 SLOWLY OPEN valve SALW-V-6052N_located near the water tank

5.6.16 BR/ ADJUST pressure regulator valve SALW-PCV-6006N to 30psi (+/$3 \mathrm{psi}$ ) as indicated by pressure gauge SALW-PI-6008N on the outside of the water cabinet. $29 P 51 G$

5.6.17 BRYACTUATE the lever on relief valve SALW-PRV-6004N on the top of the ar compressor tank and hold open approximately 5 seconds. (Air system is to be at full pressure of approximately $90 \mathrm{psi}$.)

5.6.18 BA ENSURE the relief valve SALW-PRV-6004N seats properly when the lever is released.

5.6.19 B 8 ACTUATE the lever on relief valve SALW-PRV-6005N on the top of the water tank and hold open approximately 5 seconds. (Water system air pressure is to be at full pressure of approximately 30psi.)

5.6.20 BeC ENSURE the relief valve SALW-PRV-6005N seats properly when the lever is released.

5.6.21 VALVE IN air to the WFIE cabinet by performing the following steps.

5.6.22 BMSSLOWLY OPEN valves SALW-V-6051N located inside the air comptessor cabinet and SALW-V-6026N located on the outside of the air compressor cabinet.

5.6.23 Ba SLOWLY OPEN valve SALW-V-6001N located in the WFIE cabinet. (NOTE: SALW-PRV-6002N may open if pressure through SALW-PCV$6001 \mathrm{~N}$ is too high.) 
5.6.24 3 ADJUST pressure control valve SALW-PCV-6001N in the WFIE cabidet to $20 \mathrm{psi}(+/-2.5 \mathrm{psi})$ as indicated by the pressure gauge located on the face of the valve.

5.6.25 B \& SLOWLY OPEN valve SALW-V-6004N located in the WFIE cabinet.

5.6.26 BAf SLOWLY OPEN valve SALW-V-6003N located in the WFIE cabinet.

5.6.27 BAL SLOWLY OPEN valve SALW-V-6005N located in the WFIE cabinet.

5.6.28 BAfSSLOWLY OPEN valve SALW-V-6006N located in the WFIE cabinet.

5.6.29 BRf SLOWLY OPEN valve SALW-V-6007N located in the WFIE cabinet.

5.6.30 BAf SLOWLY OPEN valve SALW-V-6020N located in the WFIE cabinet.

5.6.31 B\&f SLOWLY OPEN valve SALW-V-6021N located in the WFIE cabinet.

5.6.32 B A SLOWLY OPEN valve SALW-V-6019N located in the WFIE cabinet.

5.6.33 ADJUST the air flow through the diptubes by performing the following steps.

5.6.34 BRA ADJUST flow to dip tube to $1.5 \mathrm{CFH}(+/-0.5 \mathrm{CFH})$ as indicated by

5.6.35 BA9 ADJUST flow to dip tube to $1.5 \mathrm{CFH}(+/-0.5 \mathrm{CFH})$ as indicated by SALW-FIV-6003N.

5.6.36 BAf ADJUST flow to dip tube to $1.5 \mathrm{CFH}(+/-0.5 \mathrm{CFH})$ as indicated by

5.6.37 $3 A$ ENSURE air flow from pressure regulator SALW-PCV-6007N by slowly opening valve SALW-V-6044N in the air compressor cabinet and then reclose the valve.

5.6.38 B28 ENSURE air flow from pressure regulator SALW-PCV-6008N by slowly opening valve SALW-V-6048N in the air compressor cabinet and then reclose the valve.

5.6.39 BASURE air flow from the SALW-V-6042N port at the air compressor cabibet by slowly opening valve SALW-V-6046N in the air compressor cabinet and then reclose the valve.

\section{OC INSPECTION RECORO}




\section{BAO}

5.6.40 ENSURE air flow from the drain line by slowly opening valves SALW-V$6047 \mathrm{~N}$ and SALW-V-6046Nin the air compressor cabinet and then reclose the two valves.

5.6.41 Engineer to ENSURE section 5.6 is completed and sign below.

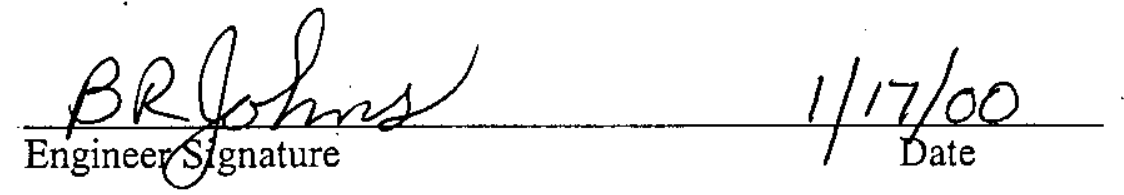

5.6.42 . Quality Assurance Inspector to VERIFY that section 5.6 is complete and sign below.

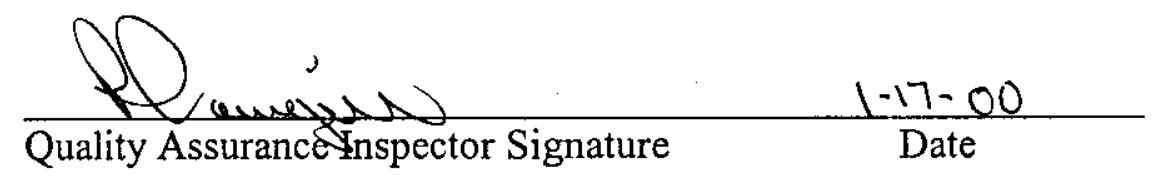




\subsection{SKID WATER DRIP SYSTEM}

5.7.1 BRA PROVIDE a container to capture water expelled from the dip tubes and the pressure relief valve SALW-PRV-6001N on the outside of the WFIE cabinet.

5.7.2 ACTUATE the Dip Tube Drip system by SLOWLY OPENING the following valves in the WFIE cabinet:

BAA) SALW-V-6016N
Beb SALW-V-6013N
Bef) SALW-V-6008N

CAUTION: Relief valve SALW-PRV-6001N will actuate and relieve pressure at 25 psig.

5.7.3 B. SLOWLY OPEN SALW-V-6018N WHILE CAREFULLY

AD USTING Pressure Regulator SALW-PCV-6005N located in the WFIE cabinet to 20psig (+/-2psig) as indicated on gauge SALW-PI-6001N in the WFIE cabinet.

5.7.4 BDYADJUST valve SALW-V-6014N to allow approximately 2 drops/second as indicated by sight glass SALW-FG-6001N.

5.7.5 BA ADJUST valve SALW-V-6015N to allow approximately 2 drops/second as indicated by sight glass SALW-FG-6002N.

5.7.6 VALVE OUT the dip tube drip system by SLOWLY CLOSING or ENSURING CLOSED the following valves located in the WFIE cabinet.

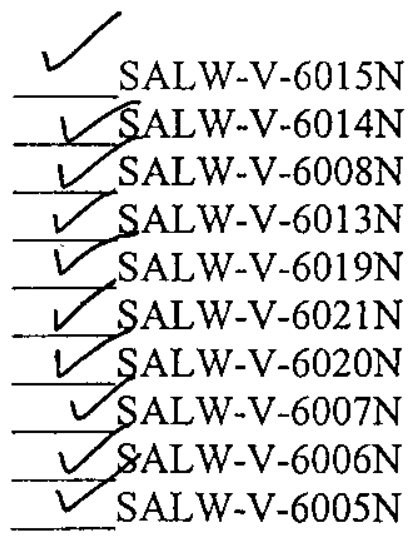


5.7.7 Engineer to ENSURE section 5.7 is completed and sign below.

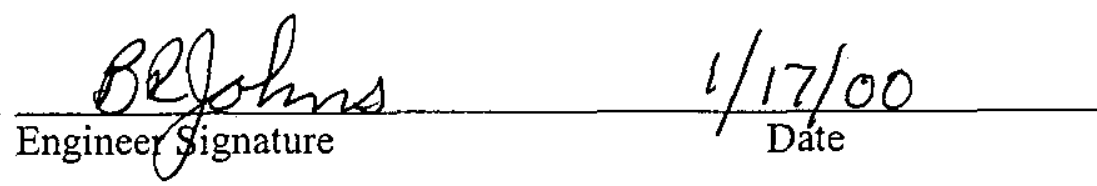

5.7.8 Quality Assurance Inspector to VERIFY that section 5.7 is complete and sign below.

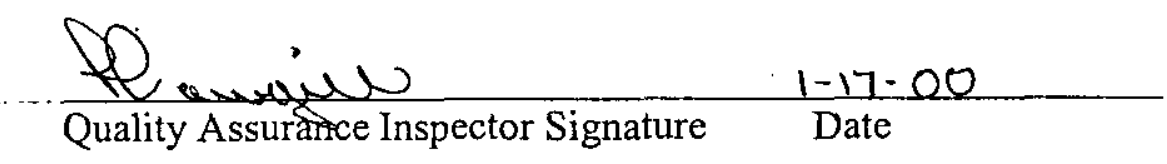




\subsection{INPUT SIGNALS TO THE PLC AND DTAM}

5.8.1
Instyament Enclosure.

5.8.2 "B G ENSURE a normally closed switch is connected to "FGM" and "CK ${ }^{+5}$ H-A" on terminal board TB4 in the Instrument Enclosure.

5.8.3 "CANSURE a normally closed switch is connected to "DIL-F" and

5.8.4 BAf ENSURE a normally closed switch is connected in parallel to the "RECIRC-1" and "RECIRC-2" wires on the Intrinsic safe terminal block in the Intrinsic Safe panel.

5.8.5 BD)ENSURE two proximity switches are connected to the intrinsic safe terminal block in the Intrinsic Safe panel. Connect a normally closed proximity switch temporarily labeled as LS-1 to "LS-1(+) and LS-1(-)" and a normally open proximity switch temporarily labeled as LS-2 to "LS-2(+) and LS-2(-)". ACTUATE the proximity switches by placing metal in front the switch faces.

5.8.6 Bl ENSURE the DIP switches for the Pepperl-Fuch module in the Intrinsic
Safopanel are set to the correct positions per H-14-103784, sheet 7 .

\section{WATER TANK LEVEL TRANSMITTER}

5.8.7 ENSURE valve SALW-V-6029N located in the water tank cabinet is
CLSSED.

5.8.8 ENSURE valve SALW-V-6031N located in the water cabinet is CLOSED.

5.8.9 30 XCONNECT a test manometer pressure source that can output at least 62" water gauge to the HIGH PRESSURE vent/test port of level transmitter SALW-LT-6003N.

5.8.10 BA ENSURE the LOW PRESSURE vent/test port of level transmitter SAL $V$-LT-6003N is OPEN to atmosphere.

5.8.11 B R ADJUST the test manometer connected to SALW-LT-6003N to a pressure of 31 " water gauge $(+/ 1 ")$. Record reading 32.00

\section{QC INSPECTION RECORG}


$5.8 .12 \frac{3 \angle \gamma}{(+/ 2 ")}$ RECORD the water tank level reading on the DTAM. 32.131 "

5.8.13 The next step will cause a low water level alarm on the DTAM.

5.8.14 RA VERY SLOWLY DECREASE the test manometer pressure until the "PIO WATER LEVEL LOW" (alarm 9) occurs on the DTAM. (This alarm should occur between 11.75 " to 12.75 " water gauge.)

5.8.15 3. ACKNOWLEDGE the alarm at the DTAM.

5.8.16 RECORD the manometer pressure and the DTAM water level readings. Pressure on manometer 12.08 Water Level on DTAM 12,1

5.8.17 BLOWLY INCREASE the manometer pressure until the alarm clears
on the DTAM. (This should occur at approximately 15.5" water gauge.)

5.8.18 baf RECORD the manometer pressure and the DTAM water level readings. Pressure on manometer 15,44 Water Level on DTAM 15.5

5.8.19 B A ENSURE the "PIC Water" alarm indicates "norm".

5.8.20 B REMOVE the test manometer from the SALW-LT-6003N high presgure vent/test port and reinstall the vent plugs on both the high and low sides.

5.8.21 BRAOPEN valve SALW-V-6029N located in the Water Cabinet.

5.8.22 B \& OPEN valve SALW-V-6031N located in the Water Cabinet.

5.8.23 BQ ENSURE "Water Tank" reading on the DTAM shows a value in inches. Record the reading $30.2^{\prime \prime}$

\section{WEIGHT FACTOR TEST}

5.8.24 20 CONNECT a test manometer pressure source that can output at least 125 water gauge to the HIGH PRESSURE dip tube on the side of the WFIE Cabinet.

5.8.25 506 ENSURE SALW-V-6001N is CLOSED.

5.8.26 BOf ENSURE SALW-V-6005N is OPEN.

\section{AC INSPECTION RECORL}


5.8.27 BR ENSURE SALW-V-6006N is OPEN.

5.8 .28 BR ENSURE adjustment valves on SALW-FIV-6002N, SALW-FIV-6003N and 8 ALW-FIV-6004N are CLOSED.

5.8.29 BAf ENSURE SALW-WFT-6002N EQUALIZING valve located on the SALW-V-6036N 3-Valve manifold in the WFIE cabinet is CLOSED.

5.8.30 BAENSURE the LOW and HIGH side isolation valves located on the SALW-V-6036N 3-Valve manifold in the WFIE cabinet are OPEN.

5.8.31 BAS SET the test mangmeter to $125^{\prime \prime}(+/-1$ ") water gauge. Record the manometer reading. 125.0

5.8.32 BQS RECORD the "WFT" reading on the DTAM. The reading is to be 125 " $(+1,5 ") . T 23122,8$

5.8.33 BRY BLEED off the pressure on the test manometer. Leave connected for testipg the specific gravity transmitter.

5.8 .34 BA/CLOSE SALW-V-6006N.

5.8.35 B\& OPEN SALW-WFT-6002N equalizing valve located on SALW-V6030N 3-Valve manifold in the WFIE cabinet.

5.8.36 69 CLOSE the LOW and HIGH side isolation valves located on the SAdW-V-6036N 3-Valve manifold in the WFIE cabinet.

\section{SPECIFIC GRAVITY TRANSMITTER}

5.8.37 BRO ENSURE SALW-V-6007N is OPEN.

5.8.38 BRY ENSURE SALW-V-6005N is OPEN. 5.8.39 DA ENSURE the LOW and HIGH side isolation valves located on SALW-
V-6035N 3-Valve manifold in the WFIE cabinet are OPEN.

5.8.40 BD. ENSURE the specific gravity transmitter equalizing valve located on the \$ALW-V-6035N 3-Valve manifold located in the WFIE cabinet is CLOSED.

5.8.41 B 84 SET the test manometer to 5 "water gauge ( $\left.+/-0.3^{\prime \prime}\right)$.

$$
5.21
$$

\section{AC INSPECTION RECDRG


5.8.42 B 8 RECORD the "SGT" reading on the DTAM. Reading to be 5" +1 $0.35^{\circ} \cdot 5.20$

5.8.43 3 \& $\mathrm{BLEED}$ off pressure on the manometer.

5.8.44 BRA ENSURE "SGT LOW". alarm occurs (alarm 13).

5.8.45 B.y ACKNOWLEDGE the alarm.

5.8.46 DISCONNECT the test manometer.

5.8.47 BD24 CLOSE SALW-V-6007N.

5.8.48 39. CLOSE SALW-V-6005N.

5.8.49 BQ OPEN SALW-SGT-6001N equalizing valve located on SALW-V603 N 3-Valve manifold in the WFIE cabinet.

5.8.50 BRYCLOSE the LOW side and HIGH side isolation valves located on SAfW-V-6035N 3-Valve manifold in the WFIE cabinet.

\section{FLOW METER SIGNAL CHECK}

5.8.51 N/A IF necessary, ENSURE a brain terminal is connected to flow converter SALW-FQIT-6001N located in the Instrument Enclosure. Use switches ar frout face BRl

5.8.52 BA. SIMULATE a flow signal of 4.0gpm (50\% span) with the hand-held braih terminal or from the flow converter face switches.

5.8.53 32 RECORD the flow readings on the front of the flow converter and on the TAM (PMP FLOW). Readings to be $4.0+/-0.4 \mathrm{gpm}$.

Flow converter 4.00 DTAM (PMP FLOW) 4.00

5.8.54 Ba RESTORE the flow converter, SALW-FQIT-6001N to its original conffyguration.

\section{QC INSPECTION RECORI}




\section{SUCTION AND DISCHARGE PRESSURE SIGNAL}

5.8.55 BR/ENSURE a current source is connected to PSPT+ and PSPT- on the intripsic side terminal board in the Intrinsic Safe panel. Set the source to "transmitter simulate."

5.8.56 BAT SET the current source to approximately $4 \mathrm{~mA}$ and record the suction pressure reading on SALW-PI-6012N. Reading to be approximately zero.

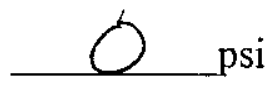

5.8.57 30 SET the current source to approximately $20 \mathrm{~mA}$ and record the suction pressure reading on SALW-PI-6012N. Reading to be approximately 100psi.

$100.0 \mathrm{psi}$

5.8.58 B DISCONNECT the current source.

5.8.59 BAENSURE a current source is connected to PDPT+ and PDPT- at the intrinsic side terminal board in the Intrinsic Safe panel. Set the source to transmitter simulate.

5.8.60 B8Y SET the current source to approximately $4 \mathrm{~mA}$ and record the discharge pressures on SALW-PI-6011N and on the DTAM. Readings should be approximately zero.

SALW-PI-6011N . . _ psi DTAM (PMP DISC) $\bigcirc \quad$ psi

5.8.61 BQ SET the current source to approximately $20 \mathrm{~mA}$ and record the diseharge pressures on SALW-PI-6011N and on the DTAM. Readings should be approximately 300 psi.

SALW-PI-6011N 299.8 psi DTAM (PMP DISC) 299 psi

$5.8 .62 B A$ DISCONNECT the current source.

\section{PIT FLAMMABLE GAS MONITOR ANALOG SIGNAL TO PLC}

5.8.63 BQW/ENSURE a current source is connected to terminal board TB1 in the Insthument Enclosure, points FGM $O(+)$ and FGM $O(-)$

5.8.64 3 SET the current source to approximately $4 \mathrm{~mA}$. 
5.8.65 BAfRECORD the "FGM" percent reading from the DTAM. Reading is to be approximately zero. $\%$

5.8.66 BPY SET the current source to approximately $10 \mathrm{~mA}$.

5.8.67 RECORD the "FGM" percent reading from the DTAM. Reading is to be approximately $11 \% .+1,3 \%$

5.8.68 $B$ S SET the current source to approximately $20 \mathrm{~mA}$.

5.8.69 BRARECORD the "FGM" percent reading from the DTAM. Reading is to be approximately $30 \%$. $30,0 \%$

5.8.70 BADISCONNECT the current source.

\section{DOME SPACE FLAMMABLE GAS MONITOR ANALOG SIGNAL TO PLC}

5.8.71 34 ENSURE a current source is connected to terminal board TB1 in the

5.8.72 BASET the current source to approximately $4 \mathrm{~mA}$.

5.8.73 B R R RECORD the "FGM" percent reading from the DTAM. Reading is to be approximately zero. $\%$

5.8.74 BAYSET the current source to approximately $10 \mathrm{~mA}$.

5.8.75 BA RECORD the "FGM" percent reading from the DTAM. Reading is to be approximately $11 \% .11,3 \%$

5.8.76 BQ SET the current source to approximately $20 \mathrm{~mA}$.

5.8.77 B4 RECORD the "FGM" percent reading from the DTAM. Reading is to be approximately $30 \%$. 30.0 \%

5.8.78 BQ DISCONNECT the current source.

\section{THERMOCOUPLE INPUTS TO THE PLC}

5.8.79 BAWWARM thermocouple SALW-TE-6004N located in the Instrument
Encidsure.

5.8.80 Bly ENSURE the "PLC CAB temp" on the DTAM displays a temperature

\section{AC INSPECTION RECORO}


5.8.81 BA CONTINUE to warm the thermocouple until "PLC Enclosure HI" (alarth 10) occurs. This will be approximately 130 degrees $F$.

5.8.82 B\& ACKNOWLEDGE the alarm.

5.8.83 BA ANSURE "PLC CAB temp" on the DTAM shows a temperature DECREASE after the heat source is removed from the SALW-TE-6004N thermocouple. 5.8.84 BADENSURE the "PLC temp" alarm returns to "norm" when the

5.8.85 WARM thermocouple SALW-TE-6003N located in the Air Compressor
Cabinet.

5.8.86 1 AENSURE the "COMPRS temp" on the DTAM displays a temperature 5.8.87 1 CONTINUE to warm the thermocouple until "Air Compressor Temp

5.8.88 BACKNOWLEDGE the alarm.

5.8.89 BQ ENSURE "COMPRS temp" on the DTAM shows a temperature DECREASE after the heat source is removed from the SALW-TE-6003N thermocouple.

5.8.90 BMP ENSURE the "CMPRSR temp" alarm returns to "norm" when the temperature decreases below 125 degrees $\mathrm{F}$.

5.8.91 BQ COOL the thermocouple probe in the WFIE cabinet with such as ice water or cool air spray. Temperature needs to drop below 35 degrees $F$.

50 Exception 1 bR)

5.8.92 BU. ENSURE alarm 30 , "WFIE CAB Temp Low" occurs at the DTAM.

5.8.93 WWARM or ALLOW to warm the thermocouple probe in the WFIE cabiret and ENSURE the "WFIE CAB Temp" alarm is "norm".

5.8.94 BACOOL the thermocouple probe in the Water cabinet with such as ice watef or cool air spray. Temperature needs to drop below 35 degrees $F$.

5.8.96 BAD WARM or ALLOW to warm the thermocouple probe in the Water cabinlet and ENSURE the "WATER CAB Temp" alarm is "norm".

\section{AC INSPECYION RECORG}


5.8.97 64. CONNECT a temperature simulator to the intrinsic side of the top thefmocouple module (MTL 3081) in the Intrinsic Safe panel.

5.8.98 Bef SET the temperature simulator to approximately 140 degrees $F$. 5.8.99 BA ENSURE the "PUMP temp" reads approximately 140 degree at the

5.8.100 BADENSURE the "Jmp Htr" is ON at the DTAM.

5.8.101 DECREASE the temperature simulator to approximately 39 degrees or lower until alarm 8 "Pump/Jumper Temp Trouble" alarms on the DTAM.

5.8.102 ACKNOWLEDGE the alarm.

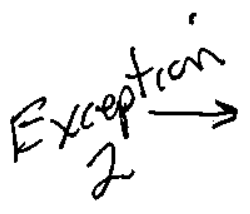

5.8.103 BASDISCONNECT the temperature simulator.

5.8.104 BR CONNECT a temperature simulator to the intrinsic side of the second thermocouple module (MTL 3081) in the Intrinsic Safe panel.

5.8.105 BA SET the temperature simulator to approximately 140 degrees $\mathrm{F}$.

5.8.106 FA ENSURE the "JMPER TEMP" reads approximately 140 degree at the DTAM.

5.8.107 BA. ENSURE the "Jmp Htr" is ON at the DTAM.

5.8.108 BAENSTRE the switch installed on TB4 between points "FGM" and "CKO5H-A" is in the CLOSED position.

5.8.109 BRAENSURE approximately $120 \mathrm{vac}$ between HT-1 and CKT3-N at TB12.

5.8.110 BA WHILE MONITORING the voltage at TB12, INCREASE the temperature to 206 degrees $F$ or higher until the voltage at TB12 goes to approximately zero. 208 on DTAM

5.8.111 BA WHILE MONITORING the voltage at TB12, decrease the temperature to 194 degrees $F$ or lower until the voltage at TB12 goes to approximately $120 \mathrm{vac}$. $192^{\circ} \mathrm{F}$ on simulaby

5.8.112 BA 6PEN the switch on TB4 that is across "FGM" and "CKT5H-A".

5.8.113 BR ENSURE the voltage at TB12 goes to approximately zero.

5.8.114 30. CLOSE the switch on TB4 that is across "FGM" and "CKT5H-A". 
5.8.115 BO ENSURE the voltage at TB12 returns to approximately $120 \mathrm{vac}$.

5.8.116 60 TURN OFF the heat trace from the DTAM.

5.8.117 BR ENSURE the voltage at TB12 goes to approximately zero.

5.8.118 BR TURN ON the heat trace from the DTAM.

5.8.119 BAA ENSURE the voltage at TB12 returns to approximately $120 \mathrm{vac}$.

5.8.120 B 4 INCREASE the temperature simulator to approximately 226 degrees or higher until alarm 8 "Pump/Jumper Temp Trouble" alarms on the DTAM.

5.8.121 $\beta$ ACKNOWLEDGE the alarm.

5.8.122 38 DISCONNECT the temperature simulator.

5.8.123 N/A ENSURE the "IMPR HT" alarm returns to "norm" on the DTAM.

5.8.124Engineer to Ensure section 5.8 is completed and sign below.

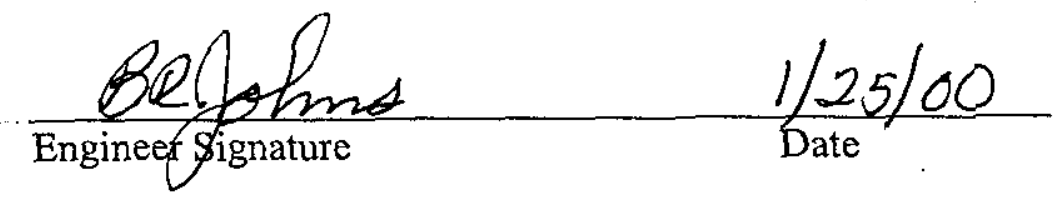

5.8.125Quality Assurance Inspector to Verify that section 5.8 is complete and sign below.

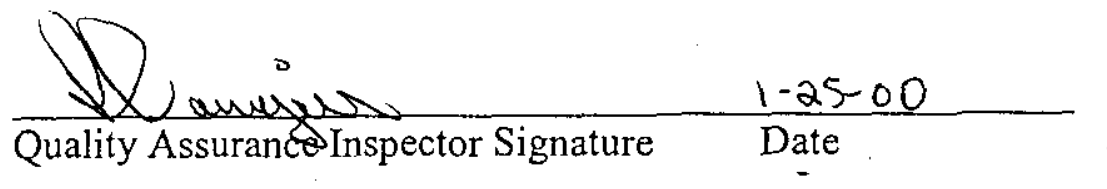

\section{QC INSPECTION RECORD}




\subsection{JET PUMP INTERLOCK CIRCUITS}

5.9.1 B ENSURE the two leak detector probes, LS-1 and LS-2 proximity switches, the FGM switch at TB4, Dilution switch at TB4, and the Recirc switch at the Intrinsic Safe panel are in place as per steps 5.8.1 to 5.8.7.

5.9.2 BQUTF POSSIBLE, CONNECT three current sources to the following points. One to JFPT+ and JFPT-in the Intrinsic Safe panel at the intrinsic terminal board; one to RFPT+ and RFPT- in the Instrument Enclosure at TB2; and one to PXPT + and PXPT- at the intrinsic terminal board in the Intrinsic safe panel. Set the current sources to "transmitter simulate" and at $6 \mathrm{~mA}$. NOTE: If three current sources are not available, then software forces will be used during this section to bypass the inputs not being tested.

5.9.3 BPS CONNECT the laptop computer to the PLC to set forces and observe

\section{RECIRCULATION FLUSH PRESSURE SIGNAL TO PLC}

5.9.4 BAD ENSURE a current source is connected to points RFPT+ and RFPT- in the Instrument Enclosure at TB2 and is set to approximately $6 \mathrm{~mA}$.

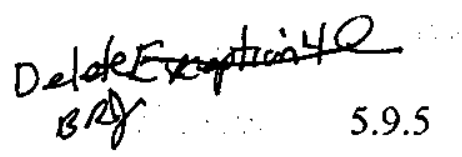

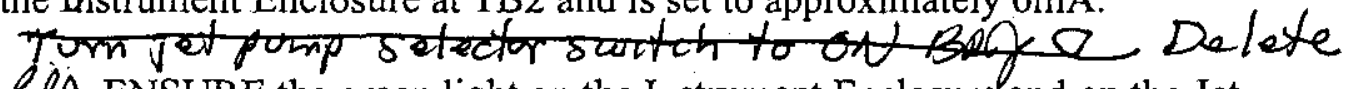
begENSURE the green light on the Instrument Enclosure and on the Jet Pump motor starter are ON.

5.9.6 A APPLY software forces to allow the jet pump to start. (Engineering will (apply the forces from the laptop computer connected to the PLC.)

5.9.7 BR/TURN the selector switch on the Jet Pump Motor Starter to ON.

5.9.8 320 START the jet pump from the DTAM and OBSERVE that the red lights at the Instrument Enclosure and motor starter come $\mathrm{ON}$ and the green lights at both locations turn OFF. 
5.9.9 SLOWLY INCREASE the current source output to approximately $12.5 \mathrm{~mA}$ or until the pump shuts down after a 3 second delay. OBSERVE the following: (Acknowledge the alarms as necessary to observe all the alarms.) NOTE: The horn sound can be adjusted by turning the set screw on the front of the horn for sound level as directed by the engineer or PIC.

Record current reading on current source. $12,12 \mathrm{~mA}$

The strobe light flashes and the horn sounds.

$\checkmark$ Alarm 12 occurs, "JET PUMP SHUTDOWN".

$\checkmark$ Alarm 39 occurs, "RECIRC FLUSH PRESS HI".

$\checkmark$ Red lights at the motor starter and Instrument Enclosure are OFF.

Green lights at the motor starter and Instrument Enclosure are $O N$.

$\checkmark$ The "RECR FL PR" is approximately $15 \mathrm{psi} .15,3$. psi

Ensure addresses $\mathrm{N} 20: 32 / 2$ and N20:32/6 are actuated as observed on the laptop computer in ladder 5 .

5.9.10 40 DECREASE the current source to approximately $4 \mathrm{~mA}$.

5.9.11 BRYENSURE the "Recirc Press" alarm at the DTAM returns to "norm".

5.9 .12 OAf ENSURE address N20:32/6 clears as observed on the laptop.

5.9.13 BAf DECREASE the current source to zero.

5.9 .14 BU ENSURE alarm 14, "RFPT SIGNAL LOSS ALARM" occurs.

5.9.15 BA. ACKNOWLEDGE the alarm.

5.9.16 8 ENSURE address N20:32/7 is actuated as observed on the laptop.

5.9.17 B INCREASE the current source to approximately $6 \mathrm{~mA}$.

5.9.18 BAN ENSURE the "RFPT SIGNAL" alarm retums to "norm" on the DTAM.

5.9.19 BAN ENSURE address N20:32/7 clears as observed on the laptop.

\section{JUMPER FLUSH PRESSURE SIGNAL TO PLC}

5.9.20 BNSURE a current source is connected to points JFPT+ and JFPT- in the Intrinsic Safe panel intrinsic terminal board and is set to approximately $6 \mathrm{~mA}$.

5.9.21
Pump motor starter are ON.

\section{QC INSPECTION RECORE}


5.9.22 6 APPLY software forces to allow the jet pump to start. (Engineering willapply the forces from the laptop computer connected to the PLC.)

5.9.23 BAYSTART the jet pump from the DTAM and OBSERVE that the red lights at the Instrument Enclosure and motor starter come $O N$ and the green lights at both locations turn $\mathrm{OFF}$.

5.9.24 BDA ENSURE address N20:32/2 is clear as observed on the laptop.

5.9.25 BODSOWLY NCREASE the current source output to approximately 12.5mA or until the pump shuts down after a 3 second delay. OBSERVE the following: (Acknowledge the alarms as necessary to observe all the alarms.)

Record current reading on current source. $12,05 \mathrm{~mA}$

\Alarm 12 occurs, "JET PUMP SHUTDOWN".

$\checkmark$ Alarm 3 occurs, "Flush Pressure HI".

Blue light at the Instrument Enclosure is $\mathrm{ON}$.

$\checkmark$ Red lights at the motor starter and Instrument Enclosure are OFF.

Green lights at the motor starter and Instrument Enclosure are ON.

1 The "PS2 FL PR" is approximately 15psi. 15.1 psi

$\checkmark$ The horn sounded and the strobe light flashed upon pump shutdown.

$\checkmark$ Ensure address N20:32/5 is actuated as observed on the laptop.

5.9.26 BAYDECREASE the current source to approximately $4 \mathrm{~mA}$.

5.9.27 BANSURE the "Flush Press" alarm at the DTAM returns to "norm".

5.9.28 B84 ENSURE the blue light at the Instrument Enclosure turns OFF.

5.9.29 BOf ENSURE address N20:32/5 clears as observed on the laptop.

5.9.30 BQQ DECREASE the current source to zero.

5.9.31 BaO ENSURE alarm 16, "JFPT SIGNAL LOSS ALARM" occurs.

5.9.32 398. ACKNOWLEDGE the alarm.

5.9.33 BolfENSURE address N20:32/8 actuates as observed on the laptop.

5.9 .3430 INCREASE the current source to approximately $6 \mathrm{~mA}$.

5.9.35 $\mathrm{B}$.ENSURE the "JFPT SIGNAL" alarm returns to "norm" on the DTAM.

5.9.36 5 ENSURE address N20:32/8 clears as observed on the laptop.

\section{QC INSPECTION RECDRO}




\section{TRANSFER PRESSURE INTERLOCK INPUT}

5.9.37 BA ENSURE a current source is connected to points PXPT+ and PXPT- in the Chtrinsic Safe panel intrinsic terminal board and is set to approximately $6 \mathrm{~mA}$.

5.9.38 BAY ENSURE the laptop computer is connected to the PLC and is "on-line".

5.9.31 31 ENSURE the green light on the Instrument Enclosure and on the Jet
Pump motor starter are ON. 5.9.32
will Apply the forces from the laptop computer connected to the PLC.)

5.9.33 BSTART the jet pump from the DTAM and OBSERVE that the red lights at the Instrument Enclosure and motor starter come $O N$ and the green lights at both locations tum OFF.

5.9.34 BAS DECREASE the current source to approximately $4.8 \mathrm{~mA}$ or until Timer 4.1 on the ladder logic of the PLC (rung 0 of ladder 5) starts timing.

5.9.35 BROENSURE the amber light on the Instrument Enclosure tums ON immediately after the timer starts. 5.9.36 BAf ENSURE after 30 seconds, the following occurs: (Acknowledge alarms
as necessary to view all the alarms.)

"XFR Pressure LOW" (alarm 1) occurs at the DTAM.

$\checkmark$ "JET PUMP SHUTDOWN" (alarm12) occurs at the DTAM.

1 Red lights at the motor starter and Instrument Enclosure are OFF.

$\checkmark$ Green lights at the motor starter and Instrument Enclosure are ON.

The horn sounded and the strobe light flashed upon pump shutdown.

5.9 .37 BAA NCREASE the current source to approximately $6 \mathrm{~mA}$ to clear the low pressure alarm.

5.9.38 BOf ENSURE the "XFR Pressure" alarm is "norm" on the DTAM.

5.9.39 START the pump from the DTAM.

5.9.40 BO INCREASE the current source to approximately $11.5 \mathrm{~mA}$ or until Timer 4.2 on rung 2 of ladder 5 starts timing as observed on the laptop computer.

\section{OC INSPECTION RECORO}

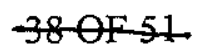

PAGE A $3 \underline{3}$ OF A 50 
5.9.41 ENA ENSURE after a 3 second delay, the following occurs: (Acknowledge alarms as necessary to view all the alarms.)

"XFR Pressure HIGH" (alarm 2) occurs at the DTAM.

"JET PUMP SHUTDOWN" (alarm12) occurs at the DTAM.

Red lights at the motor starter and Instrument Enclosure are OFF.

$\checkmark$ Green lights at the motor starter and Instrument Enclosure are ON.

The hom sounded and the strobe light flashed upon pump shutdown.

5.9 .42 BA. DECREASE the current source to approximately $6 \mathrm{~mA}$.

5.9.43 BAYENSURE the "XFR Pressure" alarm indicates "norm" on the DTAM.

\section{JR-1 VALVE POSITION INPUT (LS-1 AND LS-2)}

5.9.44 BRySTART the pump from the DTAM.

5.9.45 BRIREMOVE the metal from the front face of LS-1.

5.9.46 BAf ENSURE the following occurs immediately: (Acknowledge alarms as necessary to view all the alarms.)
"JR-1 Position NON-PROCESS" (alarm 5) occurs at the DTAM.
"JET PUMP SHUTDOWN" (alarm12) occurs at the DTAM.
2 Red lights at the motor starter and Instrument Enclosure are OFF.
Green lights at the motor starter and Instrument Enclosure are ON.
$\checkmark$ The horn sounded and the strobe light flashed upon pump shutdown.
VAddress N20:32/0 on ladder 5 is actuated as observed on the laptop.

5.9.47 BRAREMOVE the metal form the front face of LS-2.

5.9.48 B.4. ENSURE the "JR-1" still indicates "NON-PROCESS" at the DTAM.

5.9.49 Bab ENSURE address N20:32/1 is actuated on ladder 5 as observed on the laptop.

5.9.50 336 REPLACE the metal in front of LS-1 and LS-2.

5.9.51 B. ENSURE the "JR-1" indicates "norm" on the DTAM and addresses $\mathrm{N} 20132 / 0$ and N20:32/1 are clear on ladder 5 as observed on the laptop.

\section{FLAMMABLE GAS MONITOR INTERLOCK INPUT}

5.9.52 START the pump from the DTAM.

5.9.53 OPEN the FGM switch at TB4.

\section{QC INSPECTION RECORC}


5.9.54 140 ENSURE the following occurs immediately: (Acknowledge alarms as necessary to view the alarms.)

"FLAMMABLE GAS HIGH" (alarm 22) occurs at the DTAM.

$\checkmark$ "JET PUMP SHUTDOWN" (alarm12) occurs at the DTAM.

Red lights at the motor starter and Instrument Enclosure are OFF.

$\checkmark$ Green lights at the motor starter and Instrument Enclosure are ON.

The horn sounded and the strobe light flashed upon pump shutdown.

5.9.55 B R CLOSE the FGM switch at TB4.

5.9.56 BRf ENSURE the "FGM" alarm indicates "norm" at the DTAM.

5.9 .57 B. START the pump from the DTAM.

5.9 .58 B OPEN the dilution switch at TB4 in the Instrument Enclosure.

5.9.58 $B$ RS ENSURE the following occurs after a 5-minute delay: (Acknowledge alams as necessary to view the alarms.)

"DILUTION TANK NO FLOW" (alarm 35) occurs at the DTAM. "JET PUMP SHUTDOWN" (alarm12) occurs at the DTAM. Ret lights at the motor starter and Instrument Enclosure are OFF. $\checkmark$ Green lights at the motor starter and Instrument Enclosure are ON. The horn sounded and the strobe light flashed upon pump shutdown.

5.9 .59 Gof CLOSE the dilution switch.

5.9 .60 BA AENSURE the "Dilution tk"

\section{RECIRCULATION LOW FLOW}

5.9.61

5.9.62 32 OPEN the Recirculation switch at the Intrinsic Safe panel.

5.9.63 32 ENSURE the following occurs after a 3-second delay: (Acknowledge alantis as necessary to view the alarms.)

$\checkmark$ "Recirculation Failure" (alarm 21) occurs at the DTAM. "JET PUMP SHUTDOWN" (alarm12) occurs at the DTAM.

Bed lights at the motor starter and Instrument Enclosure are OFF. Green lights at the motor starter and Instrument Enclosure are ON. The horn sounded and the strobe light flashed upon pump shutdown.

\section{AC IMSPECTION RECORG}


5.9.64 BRCLOSE the Recirculation switch.

5.9.65 BU ENSURE the "Recirc Loop" alarm indicates "norm" at the DTAM.

\section{LEAK DETECTION INTERLOCK}

5.9.66 ENSURE there is a water supply and bucket available to actuate the
leakldetector probes.

5.9.67 BAf START the pump from the DTAM.

5.9.68 BAY PLACE the primary leak detector probe in a bucket of water. 5.9.69 BNSURE the following occurs after a 3-second delay: (Acknowledge
alarohs as necessary to view the alarms.)

_PUMP PIT LEAK" (alarm 6) occurs at the DTAM.

$\checkmark$ "JET PUMP SHUTDOWN" (alarm12) occurs at the DTAM.

$\checkmark$ Red lights at the motor starter and Instrument Enclosure are OFF.

Green lights at the motor starter and Instrument Enclosure are ON.

$\checkmark$ The horn sounded and the strobe light flashed upon pump shutdown.

Ensure address N20:32/3 in ladder 5 actuates as observed on the laptop. 5.9.70 BREMOVE the leak detector probe from the bucket and allow the water
to dtain off.

5.9.71 AA ENSURE the "Pump Pit" leak alarm returns to "norm".

5.9.72 BAENSURE address N20:32/3 clears as observed on the laptop.

5.9.73 BASSTART the pump from the DTAM.

5.9.74 BRISCONNECT one of the "SD" wires going to the primary leak detedtor probe.

5.9.75 RAD ENSURE the following occurs after a 3-second delay: (Acknowledge alarnis as necessary to view the alarms.)

"PUMP PIT LEAK TROUBLE" (alarm 7) occurs at the DTAM.

"JET PUMP SHUTDOWN" (alarm12) occurs at the DTAM.

Red lights at the motor starter and Instrument Enclosure are OFF.

Green lights at the motor starter and Instrument Enclosure are ON.

$\checkmark$ The horn sounded and the strobe light flashed upon pump shutdown.

Ensure address N20:32/3 actuates as observed on the laptop.

5.9.76 BA. RECONNECT the "SD" wire.

AC IASPECTION RECORG 
5.9.77 A ENSURE the "Pump Pit" trouble alarm indicates "norm" on the DTKM.

5.9.78 BA ENSURE address N20:32/3 clears as observed on the laptop.

5.9.79 Ba START the pump from the DTAM.

5.9.80 30 PLACE the leak detector 1 probe in a bucket of water.

5.9.81 3A ENSURE the following occurs after a 3-second delay: (Acknowledge alarms as necessary to view the alarms.)

$\checkmark$ "LEAK DETECTOR NO 1 LEAK DETECTED" (alarm 18) occurs at the DTAM.

$\checkmark$ "JET PUMP SHUTDOWN" (alarm12) occurs at the DTAM.

$\checkmark$ Red lights at the motor starter and Instrument Enclosure are OFF.

$\checkmark$ Green lights at the motor starter and Instrument Enclosure are ON.

The horn sounded and the strobe light flashed upon pump shutdown.

Ensure address N20:32/4 actuates in ladder 5 as observed on the laptop.

5.9.82 BS2 $/$ REMOVE the leak detector probe from the bucket and allow the water to drain off.

5.9.83 BAY ENSURE the "Leak 1" alarm returns to "norm".

5.9.84 BAfENSURE address N20:32/4 clears as observed on the laptop.

5.9.85 BSTSTART the pump from the DTAM.

5.9.86 BAD DISCONNECT one of the "SD" wires going to the leak detector 1 probe.

5.9.87 A ENSURE the following occurs after a 3-second delay: (Acknowledge alarms as necessary to view the alarms.) DTAM "LEAK DETECTOR NO 1 TROUBLE" (alarm 19) occurs at the

$\checkmark$ "JET PUMP SHUTDOWN" (alarm12) occurs at the DTAM.

$\checkmark$ Bed lights at the motor starter and Instrument Enclosure are OFF.

Green lights at the motor starter and Instrument Enclosure are ON.

$\checkmark$ The horn sounded and the strobe light flashed upon pump shutdown.

$\checkmark$ Ensure address N20:32/4 actuates as observed by the laptop.

5.9.88 By RECONNECT the "SD" wire. 
5.9.89 BN ENSURE the "Leak $1 \mathrm{ck}$ " alarm indicates "norm" on the DTAM.

5.9.90 BANSURE address N20:32/4 clears as observed on the laptop.

5.9.91 BRD DISCONNECT the current sources from the PXPT, RFPT and JFPT ternination points.

5.9.92 B DISCONNECT the test switches from the FGM, Dilution and Reeirculation termination points.

5.9.93 BISCONNECT the proximity switches from the Intrinsic Safe panel.

5.9.94 BNEMOVE the laptop computer from the PLC.

5.9.95 BAD DISCONNECT the leak detector probes from the Instrument Enclosure.

5.9.96 Engineer to ENSURE section 5.9 is completed and sign below.

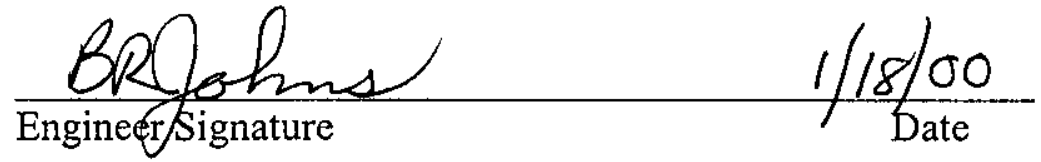

5.9.97 Quality Assurance Inspector to VERIFY that section 5.9 is completed and sign below.

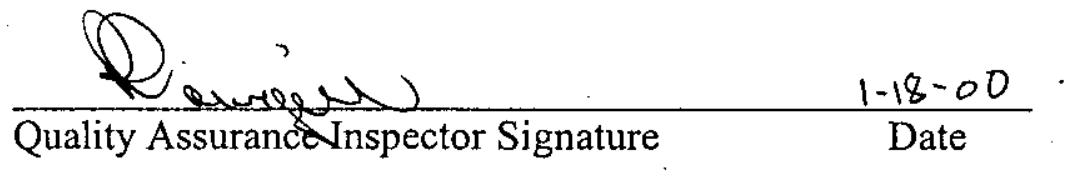




\subsection{HEATERS, AIR CONDITIONER AND LIGHTS}

5.10.1 BAY TURN the heater ON in the air compressor cabinet. Set the thermostat highenough to allow the unit to operate. 5.10.2 1 RESET the thermostat to approximately 40 degrees $F$ to allow the heat
to tufn OFF. Then unplug the heater.

5.10 .3 BAf TURN the fan thermostat switch to allow the fan in the air compressor
cablhet to run.

5.10.4 BARESET the fan switch to approximately 90 degrees $F$ to allow the fan to
turn $\mathrm{FFF}$.

5.10 .5 B TURN the heater ON in the WFIE cabinet. Set the thermostat high

5.10.6 B B RESET the thermostat to approximately 40 degrees $F$ to allow the heat
to tun OFF. Then unplug the heater.

5.10.7 B b TURN the heater ON in the Water cabinet. Set the thermostat high
enolgh to allow the unit to operate.

5.10.8 RESET the thermostat to approximately 40 degrees $F$ to allow the heat

5.10 .9 TURN the heater ON in the Instrument Enclosure. Set the thermostat
high enough to allow the unit to operate. 5.10.10 Be KRESET the thermostat to approximately 40 degrees $F$ to allow the heat
to two OFF. Then unplug the heater.

5.10.11 XURN the heater ON in the Locker. Set the thermostat high enough to
allow the unit to operate.

5.10.12 BA RESET the thermostat to approximately 40 degrees $\mathrm{F}$ to allow the heat to tuyn OFF. Then unplug the heater.

5.10 .13 b 1 TURN ON the air conditioner in the Instrument Enclosure. If necessary, remove the front grill on the unit and adjust the temperature setting to get the unit to operate.

5.10 .14 BAD RESET the temperature setting on the air conditioner to between 90 to 95 dogrees $F$. Remove the grill and filter on the front of the air conditioner for access to the adjustment. Then unplug the air conditioner.

\section{OC IASPECTION RECORL}


5.10:15 B ENSURE the light in the WFIE cabinet operates.

5.10.16 BENSURE the light in the Instrument Enclosure operates.

5.10.17Engineer to ENSURE that section 5.10 is completed and sign below.

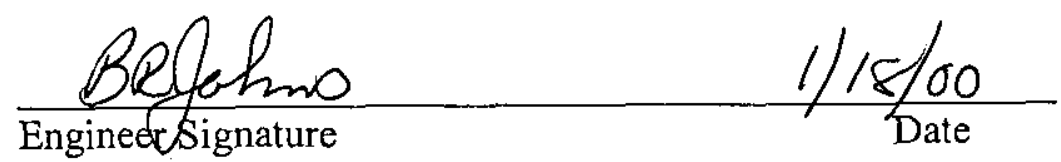

5.10.18Quality Assurance Inspector to VERIFY that section 5.10 is completed and sign below.

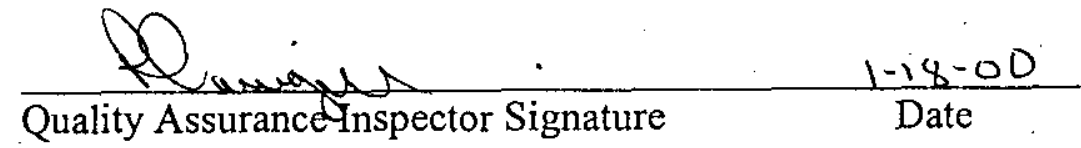


RPP-5489:

RPP-5490

REVISION 0

ACCEPTANCE TEST PROCEDURE

This page may be reproduced as necessary

PAGE of

ACCEPTANCE TEST PROCEDURE LOG

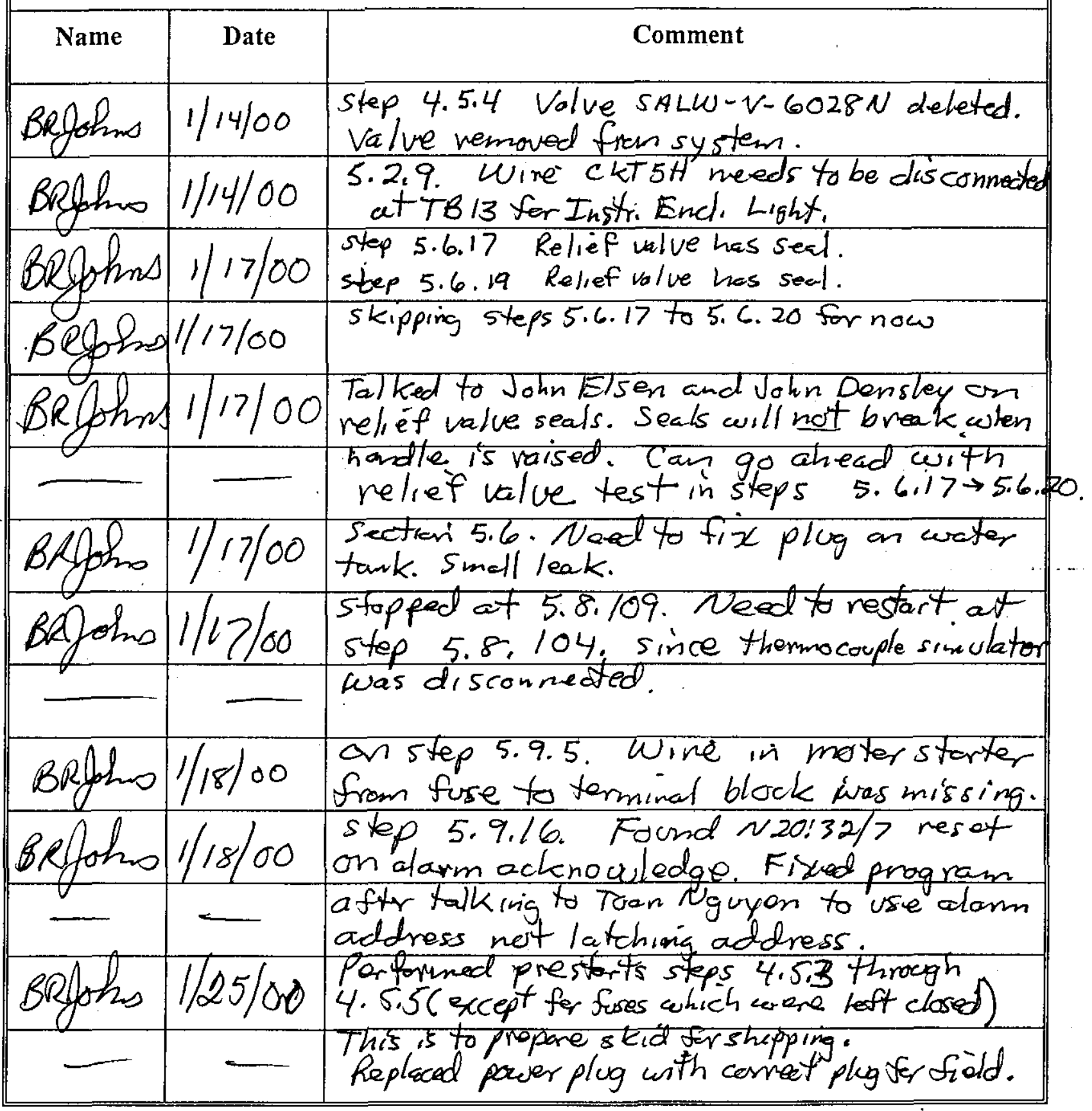

QC INSPECTION RECORD

$460 F-51-$

PAGE A 41 OF A 50

WORK ORDER

$2 \mathrm{H} 0004137 \mathrm{~F}$ 


\section{ACCEPTANCE TEST PROCEDURE EXCEPTION LOG}

This page may be reproduced as necessary

PAGE of

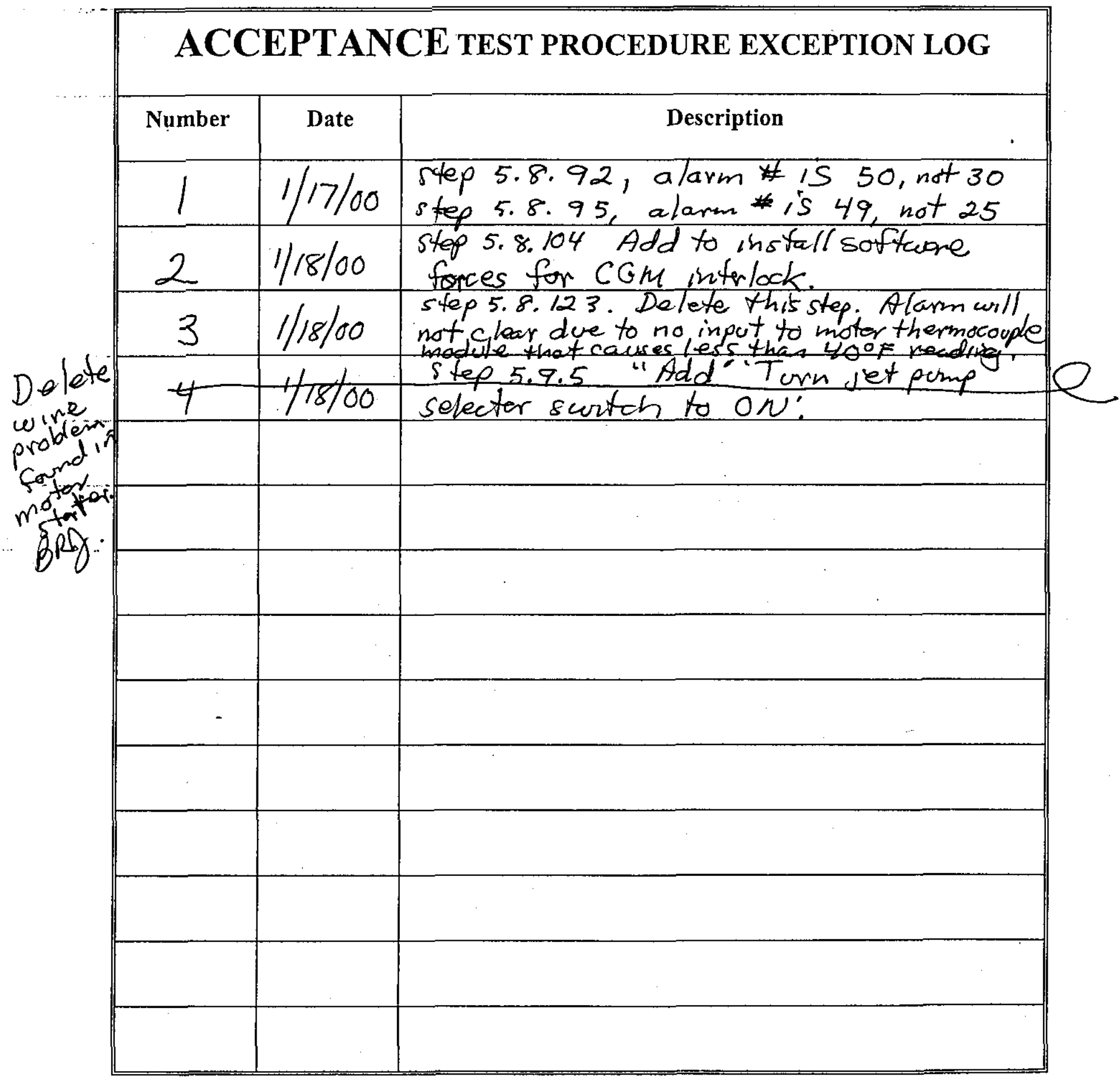

OC IASPECTION RECORG 
RPP-5489-

RPP-5490

REVISION 0

ACCEPTANCE TEST PROCEDURE EXCEPTION RECORD

This page may be reproduced as necessary.

\begin{tabular}{|l|l|}
\hline ATP step number: $5,8,104$ & ATP Exception Log Number 2 \\
\hline
\end{tabular}

Description of Exception:

CGM interlocks need to be forced out to perform temperature interlock check.

Resolution of Exception:

The software program was written for future CGM installation. In order to check the temperature interlock on the heat trace, the GGM hi alarm and CGM fault interlocks must be forced so the PLC sees a normal Cam input. Add to step 5.8.104 to connect laptop and force inputs I:8.2 and I:8.4. All forces are rem arp step 5.9.94 Date of Resolution:

$1 / 18 / 00$ Cognizant Engineer signature:

BRlohns

Quality Assurance signature:

Design Authority:

RESOLUTION COMPLETED: (date)

$\frac{1}{1,25100} 116^{1-18-00}$

Quality Assurance:

Cognizant Engineer:

8.80 
RPR-5489-

RPP-5490

REVISION 0

ACCEPTANCE TEST PROCEDURE EXCEPTION RECORD

This page may be reproduced as necessary.

\begin{tabular}{|l|l|}
\hline ATP step number: 5.8 .123 & ATP Exception Log Number 3 \\
\hline Description of Exception: "Jmpr HT" did not go to \\
\hline 'norm'. (alarm 8) \\
\hline Resolution of Exception: Delete step 5.8.123. The \\
alarm will remain in 'trouble' due to \\
no input to the pump thermocouple \\
\hline
\end{tabular}
probe. This causes $H T^{\prime}$ alarm 8 to trip due to temperature below $40^{\circ} \mathrm{F}$. This was

checked in steps 5.8.101 and 5.8.102.

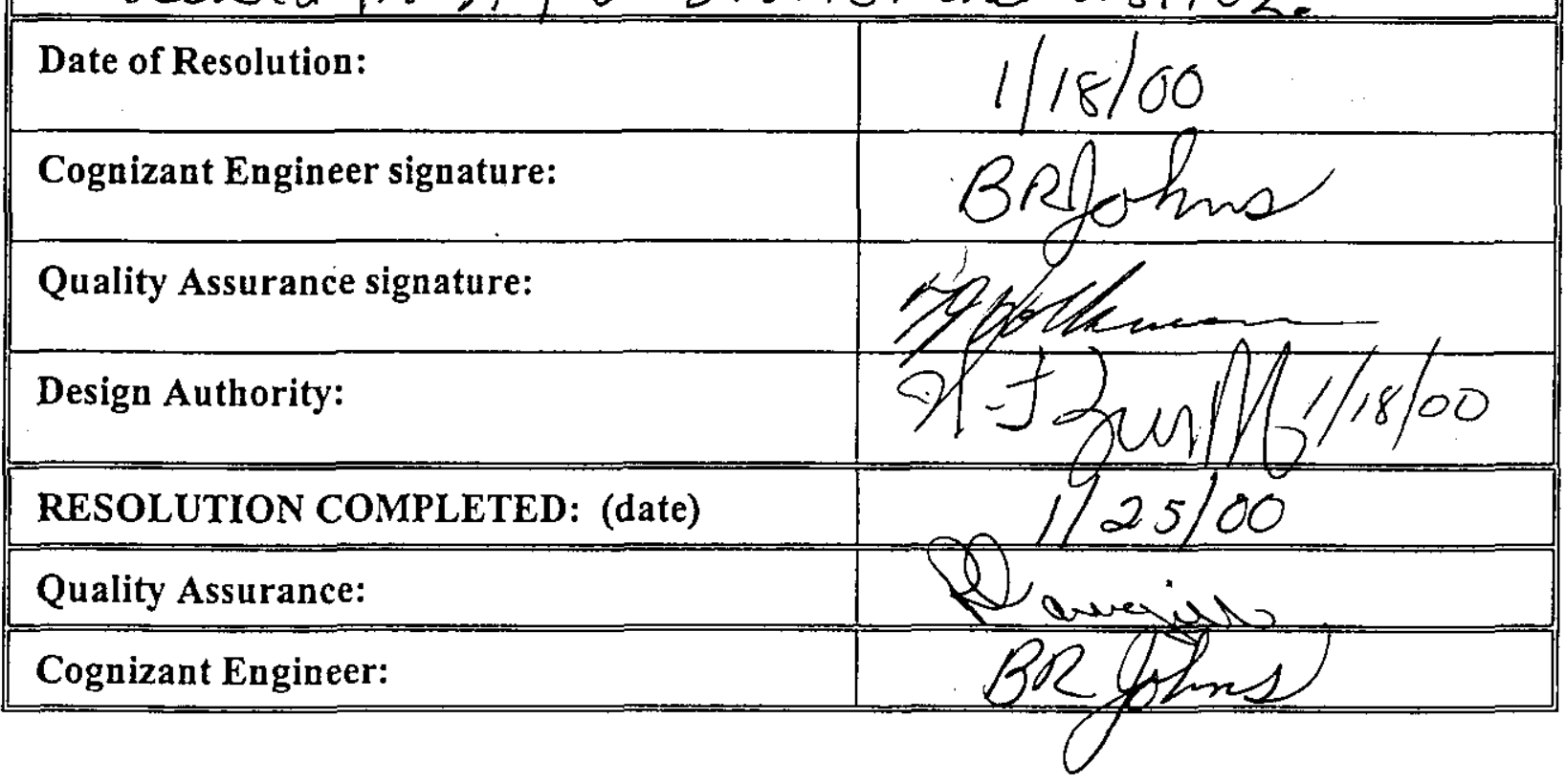

PAGE A 4 44 OF A $\underline{50}$ 
RPP-5489-

RPP-5490

REVISION 0

ACCEPTANCE TEST PROCEDURE ACCEPTANCE RECORD

This Acceptance Test Procedure has been completed and the results, including red-line changes, exceptions, and exception resolutions, have been reviewed for compliance with the intent of the Purpose (Section 1.0). The test results are accepted by the undersigned:
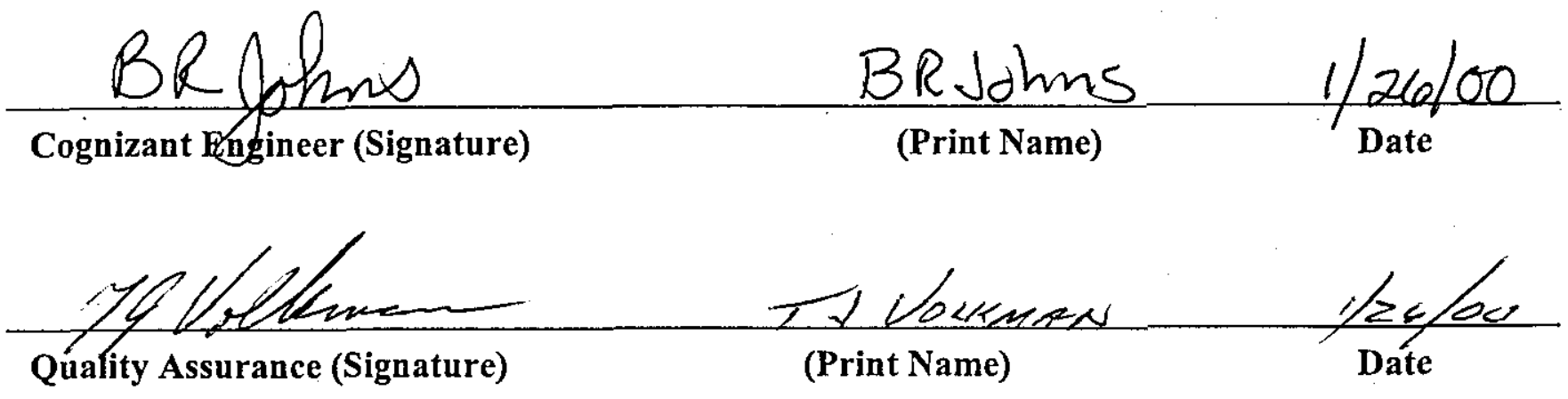

AC INSPECTION RECORD

WORK ORDER

$2 \mathrm{H} 0004137 \mathrm{~F}$ 
RP 5489

RPP-5490

REVISION 0

PROCEDURE PERFORMER SIGNATURE SHEET

All personnel who will be performing, initialing and signing the procedure shall enter their printed name, signature and initials below.

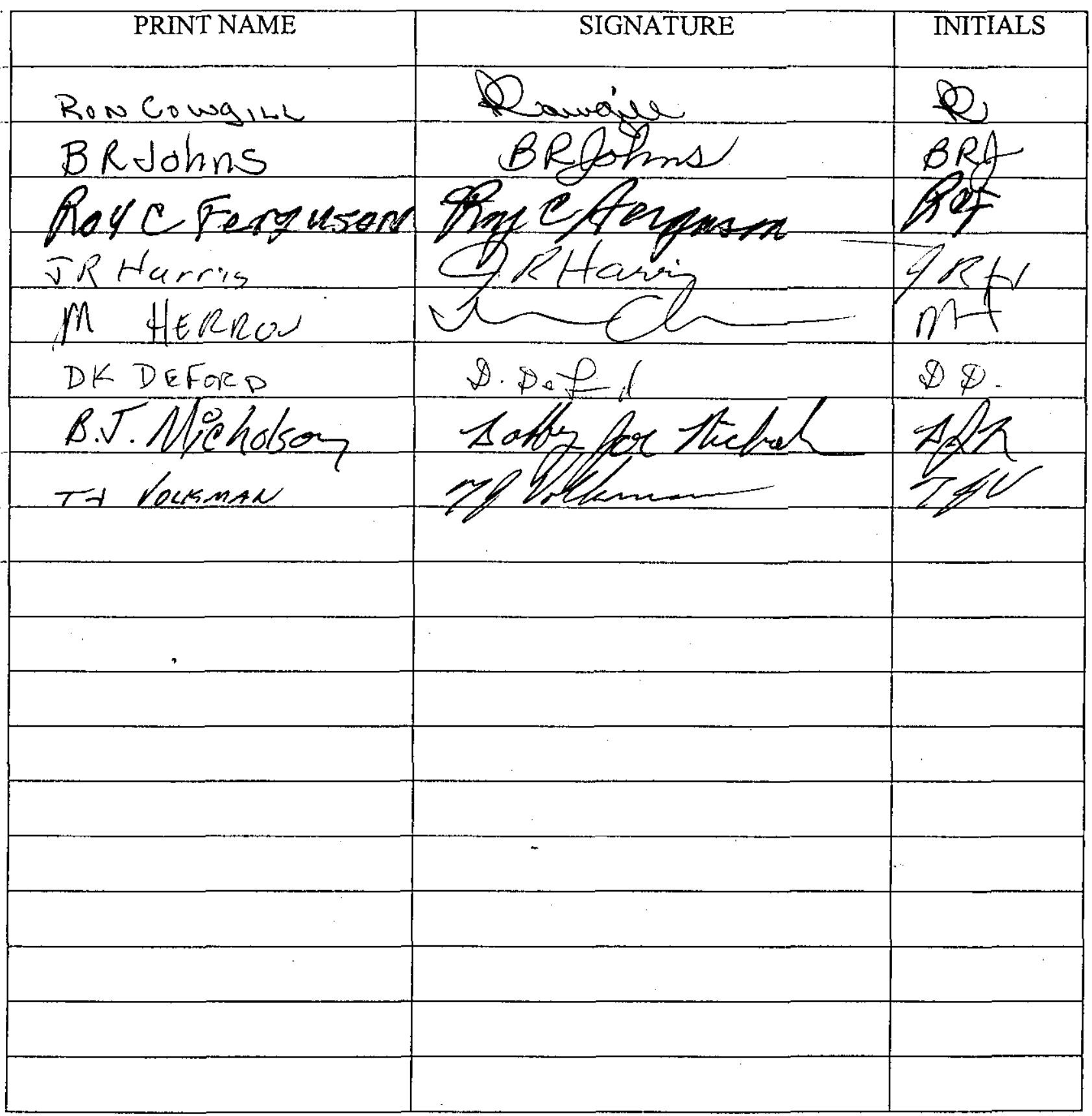

AC INSPECTION RECORD

WORK ORDER

$2 \mathrm{H} 0004137 \mathrm{~F}$ 
RPP-5489-

RPP-5490

REVISION 0

PRE-JOB BRIEF SIGNATURE PAGE

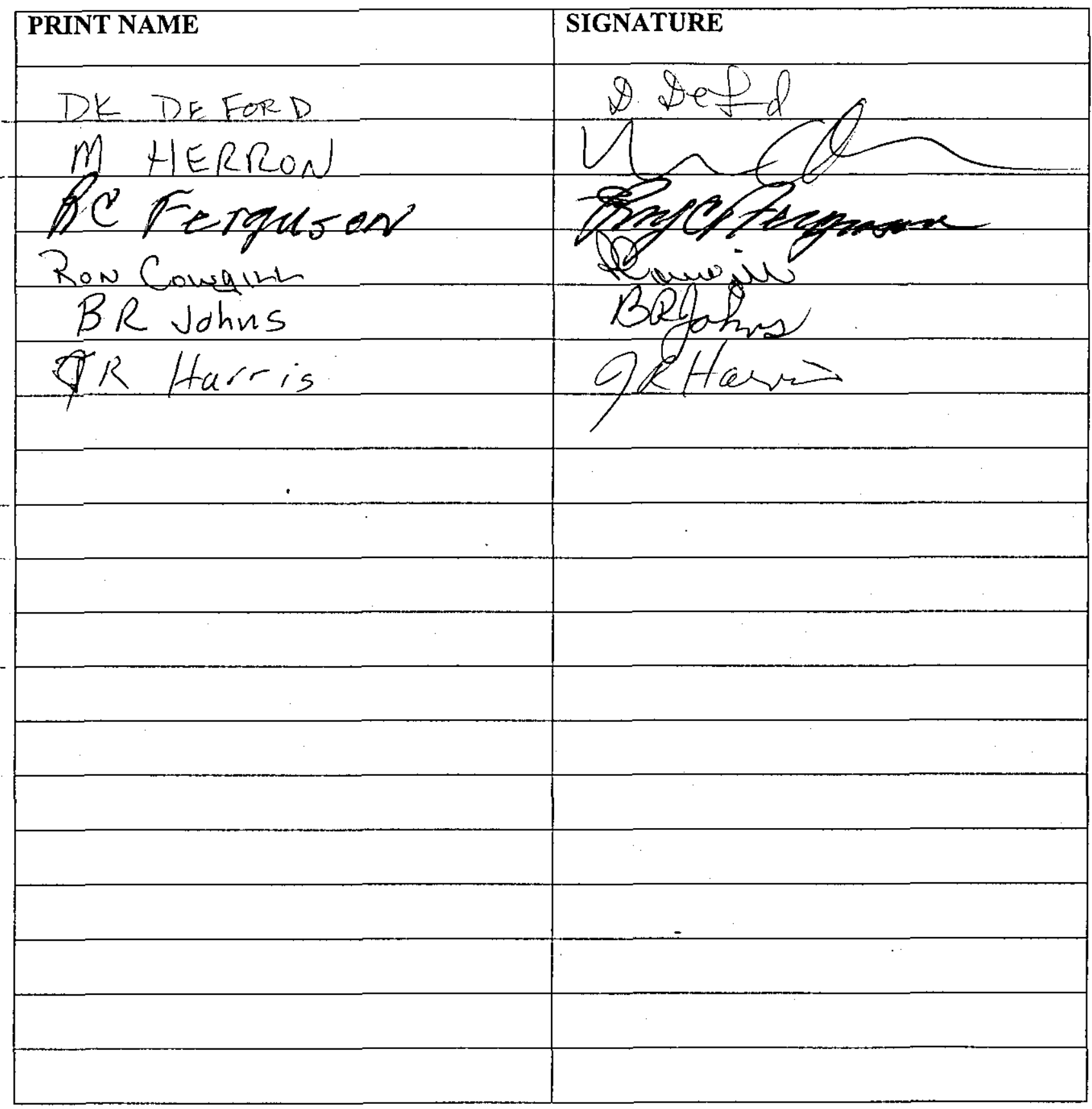

OC INSPECTION RECORD

WORK ORDER $2 \mathrm{H} 0004137 \mathrm{~F}$ 
NEC INSPECTION REPORT \\ ORIEIINAN:}

\begin{tabular}{|l|l|l|l|l|}
\hline $\begin{array}{l}\text { ProjectW.O. No. } \\
2 \mathrm{H}-00-04137 / \mathrm{F}\end{array}$ & $\begin{array}{l}\text { Building No. } \\
277 \text { West }\end{array}$ & $\begin{array}{l}\text { Code Edition } \\
\text { NEC, 1999 Edition }\end{array}$ & \multicolumn{2}{|l|}{$\begin{array}{l}\text { Report No. } \\
8168\end{array}$} \\
\hline $\begin{array}{l}\text { Inspection Requested By } \\
\text { Bruce Johns }\end{array}$ & $\begin{array}{l}\text { Phone } \\
373-3429\end{array}$ & $\begin{array}{l}\text { Inspector } \\
\text { Bresina WL }\end{array}$ & $\begin{array}{l}\text { Phone } \\
376-5265\end{array}$ & Page 1 of 1 \\
\hline
\end{tabular}

Item Inspected: Pumping instrument control skid " $\mathrm{N}$ " for tank $\mathrm{U} 109$, Salt Well Pumping per work pkg. $2 \mathrm{H}-00-04137 / \mathrm{F}$

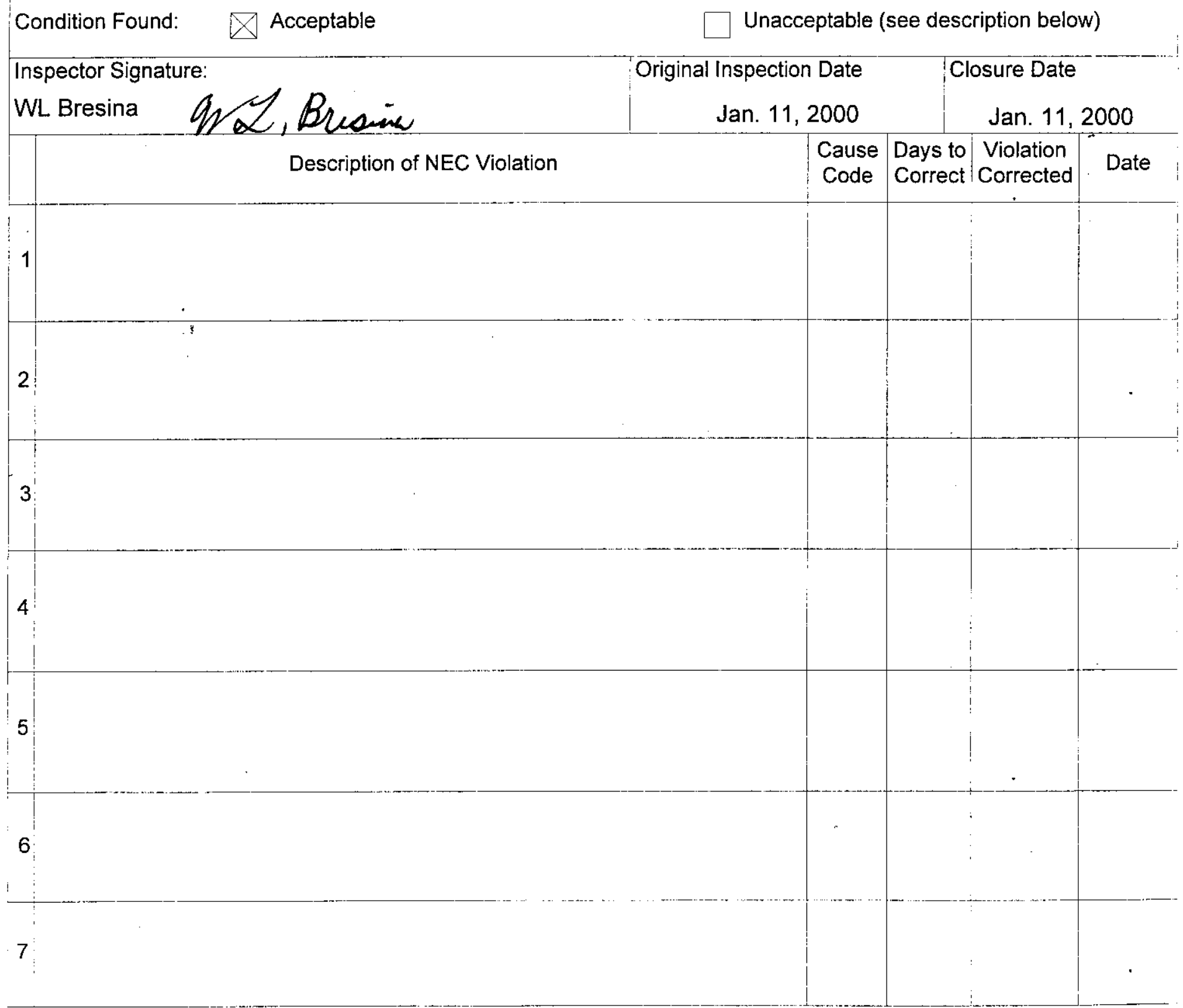

Electrical service will be discontinued for the equipment or facility identified if violations are not corrected within time allowed by the "Days to Correct" column. "Days to Correct" starts with the original inspection date. For concerns regarding this, call the Chief Electrical Engineer at 376-6347. 
UNFIRED PRESSURE VESSEL - REPORT OF INSPECTION (Form NB-7) REVISION 0 THE HARTFORD STEAM BOILER INSPECTION AND INSURANCE COMPANY, HARTFORD, CT

TPI WO NO: 2W-99-

( 1 Hrs)

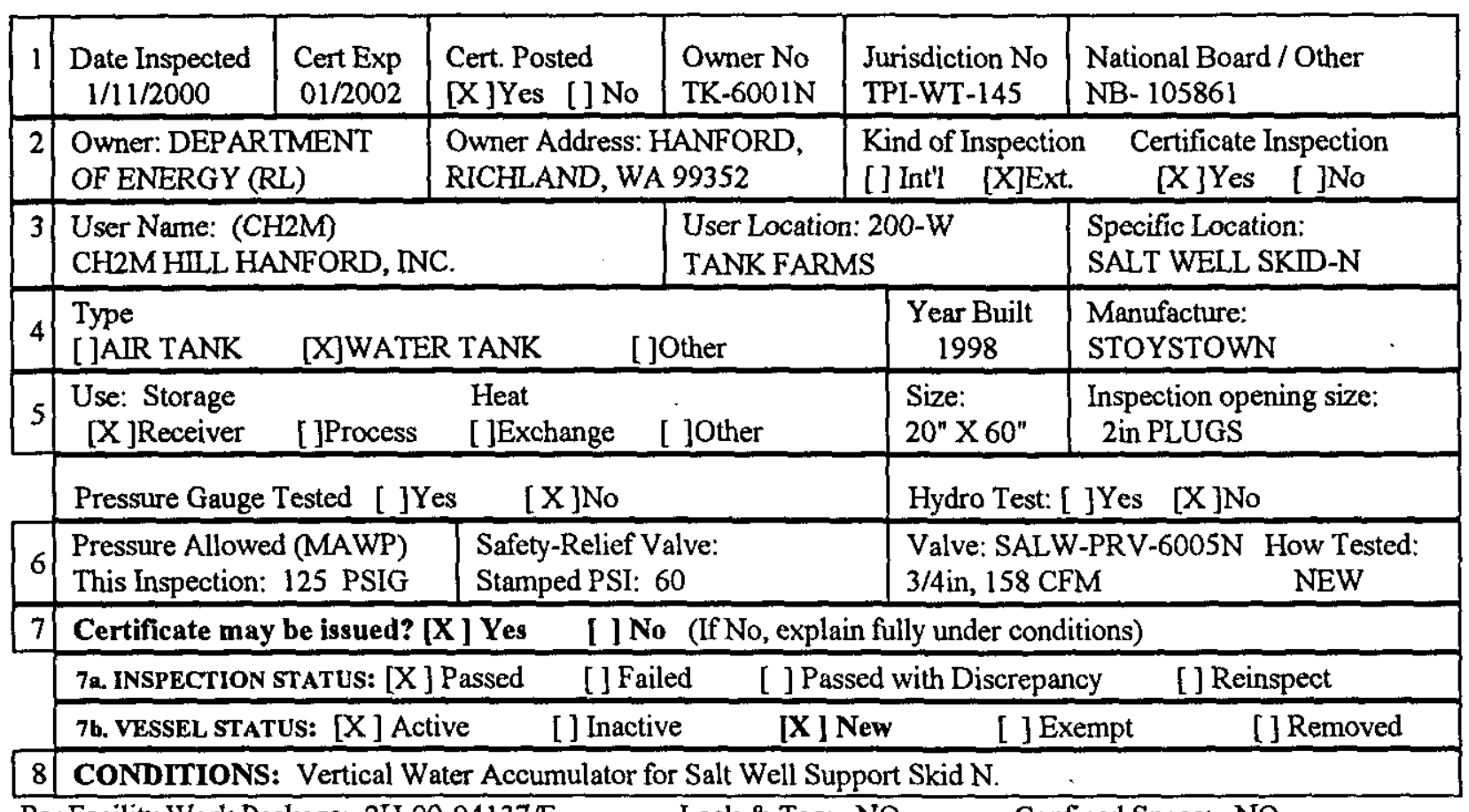

Per Facility Work Package: $2 \mathrm{H}-00-04137 / \mathrm{F}$ Lock \& Tag: NO Confined Space: №

Inspected at 277-W Fabrication Shop during final assembly. Scheduled to be located at Tank Farms

8a: Internal Inspection not done or required this inspection. Vessel is galvanized and not subject to internal corrosion.

8b: External Inspection shows no dents, damage, leakage, corrosion or excess vibration.

Pressure guage: Installed \& Proper Bottom drain: Installed \& Suitable

Safety-Relief Valve Seal was intact with no evidence of damage or tampering

9 REQUIREMENTS/RECOMMENDATIONS: The following items are to be corrected:

1. None this inspection

10 Name of Facility Contact to whom requirements were explained: Bruce Johns Tel: $373-3429 \quad$ S7-24

$\begin{array}{lllll}\text { Copies to: David Saueressig Tel: } 373-0183 & \text { S7-20, Mike Koch } & \text { Tel: } 373-2699 & \text { S7-24 }\end{array}$

I hereby Certify this is a true report of my inspection

Signature of Inspector

\begin{tabular}{|l|l|l|}
\hline Uohn L. Densley & $\begin{array}{l}\text { Commission No } \\
\text { NB-8032W }\end{array}$ & $\begin{array}{c}\text { Employed By: The Hartford Steam Boiler } \\
\text { Inspection and Insurance Co. }\end{array}$ \\
\hline
\end{tabular}

TPI-WT-145.doc 
UNFIRED PRESSURE VESSEL - REPORT OF INSPECTION (Form NB-7)REVISION 0 THE HARTFORD STEAM BOILER INSPECTION AND INSURANCE COMPANY, HARTFORD, CT

TPI WO NO: 2W-00-New

\begin{tabular}{|c|c|c|c|c|c|c|}
\hline 1 & $\begin{array}{l}\text { Date Inspected } \\
1 / 11 / 2000\end{array}$ & $\begin{array}{l}\text { Cert Exp } \\
01 / 2002\end{array}$ & $\begin{array}{l}\text { Cert. Posted } \\
\text { [X]Yes [] No }\end{array}$ & $\begin{array}{l}\text { Owner No } \\
\text { TK-6002N }\end{array}$ & $\begin{array}{l}\text { Jurisdiction No } \\
\text { TPI-WT-144 }\end{array}$ & $\begin{array}{l}\text { National Board / Other } \\
\text { NB- } 65943 \mathrm{~L}\end{array}$ \\
\hline 2 & \multicolumn{2}{|c|}{$\begin{array}{l}\text { Owner: DEPARTMENT } \\
\text { OF ENERGY (RL) }\end{array}$} & \multicolumn{2}{|c|}{$\begin{array}{l}\text { Owner Address: HANFORD, } \\
\text { RICHLAND, WA } 99352\end{array}$} & \multicolumn{2}{|c|}{$\begin{array}{l}\text { Kind of Inspection } \\
\text { Certificate Inspection } \\
\text { [] Int'] [X]Ext. } \\
{[\text { X]Yes [ ]No }}\end{array}$} \\
\hline 3 & \multicolumn{3}{|c|}{$\begin{array}{l}\text { User Name: (CH2M) } \\
\text { CH2M HANFORD,INC }\end{array}$} & \multicolumn{2}{|c|}{$\begin{array}{l}\text { User Location: } 200-\mathrm{W} \\
\text { TANK FARM }\end{array}$} & $\begin{array}{l}\text { Specific Location: } \\
\text { SALT WELL SKID -N }\end{array}$ \\
\hline 4 & \multicolumn{4}{|l|}{$\begin{array}{l}\text { Type } \\
\text { [X]AIR TANK }\end{array}$} & $\begin{array}{c}\text { Year Built } \\
1999 \\
\end{array}$ & $\begin{array}{l}\text { Manufacture: } \\
\text { BRUNNER ENG }\end{array}$ \\
\hline \multirow[t]{2}{*}{5} & $\begin{array}{l}\text { Use: Storage } \\
{[\mathrm{X}] \text { Receiver }}\end{array}$ & [ ]Process & $\begin{array}{l}\text { Heat } \\
\text { []Exchange }\end{array}$ & JOther & $\begin{array}{l}\text { Size: } \\
14^{\prime \prime} \times 20^{\prime \prime}\end{array}$ & $\begin{array}{l}\text { Inspection opening size: } \\
\text { 2" PLUGS }\end{array}$ \\
\hline & \multicolumn{4}{|c|}{ 5a.Pressure Gauge Tested [ ]Yes } & \multicolumn{2}{|c|}{ 5b. Hydro Test: [ ]Yes $[\mathrm{X}]$ No } \\
\hline 6 & \multicolumn{2}{|c|}{$\begin{array}{l}\text { Pressure Allowed (MAWP) } \\
\text { This Inspection: } 200 \text { PSIG } \\
\end{array}$} & \multicolumn{2}{|c|}{$\begin{array}{l}\text { Safety-Relief Valve: } \\
\text { Stamped PSI: } 125\end{array}$} & \multicolumn{2}{|c|}{$\begin{array}{lc}\text { Valve: SALW-PRV-6004N } & \text { How Tested: } \\
1 / 2 \text { in, } 296 \text { CFM } & \text { NEW }\end{array}$} \\
\hline \multirow[t]{3}{*}{7} & \multicolumn{6}{|c|}{ Certificate may be issued? $[X]$ Yes } \\
\hline & \multicolumn{4}{|c|}{ 72. INSPECTION STATUS: [X] Passed [] Failed } & \multicolumn{2}{|r|}{ [] Reinspect } \\
\hline & \multicolumn{4}{|c|}{ 7b. VESSEL STATUS: $[\mathrm{X}]$ Active } & \multicolumn{2}{|c|}{ [ ] Exempt } \\
\hline 8 & \multicolumn{6}{|c|}{ CONDITIONS: Small Horizontal Air Accumulator for Salt Well Support Skid N } \\
\hline
\end{tabular}

Per Facility Work Package: 2H-00-04137/F $\quad$ Lock \& Tag: NO _ Confined Space: NO

Inspected at 277-W Fabrication Shop during final assembly. Scheduled to be located at Tank Farms

8a: Internal Inspection not done or required this inspection.

Original Thickness: Shell $=\underline{0.106}$ Heads $=\underline{0.094}$

$8 \mathrm{~b}$ : External Inspection shows no dents, damage, leakage, corrosion or excess vibration.

Pressure guage: Installed \& Proper Bottom drain: Installed \& Suitable

Safety-Relief Valve Seal was intact with no evidence of damage or tampering

9 REQUIREMENTS/RECOMMENDATIONS: The following items are to be corrected:

1. None this inspection

\begin{tabular}{|l|lllllll}
\hline 10 & $\begin{array}{l}\text { Name of Facility Contact to whom requirements were explained: Bruce Johns Tel: } 373-3429 \\
\text { Copies to: David Saueressig }\end{array}$ & Tel: $373-0183-24$ & S7-20, & Mike Koch & Tel: $373-2699$ & S7-24 & \\
\hline
\end{tabular}

I hereby Certify this is a true report of my inspection

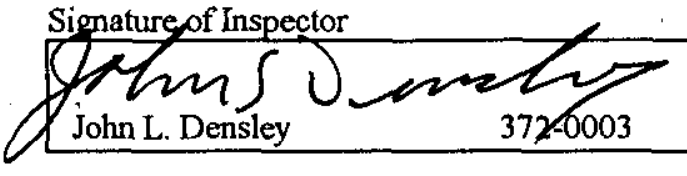

Commission No NB- $8032 \mathrm{~W}$
Employed By: The Hartford Steam Boiler Inspection and Insurance Co.

TPI-WT-144.doc 